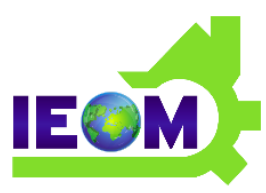

IEOM Society International

\section{International Journal of Industrial Engineering and Operations Management (IJIEOM) \\ Volume 3, No. 2, December 2021 \\ pp. $107-134$}

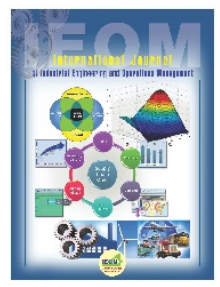

\title{
Prioritization of barriers in industrial symbiosis implementation in automotive industry - Using ISM and MICMAC Analysis
}

\author{
Vimal K.E.K \\ Department of Mechanical Engineering, National Institute of Technology Patna \\ Patna, Bihar - 800005, India \\ Email: vimalkek.engr@gmail.com \\ Asela K. Kulatunga \\ Senior Lecturer, Department of Manufacturing \& Industrial Engineering, \\ Faculty of Engineering, University of Peradeniya, \\ Peradeniya 20400, Sri Lanka \\ E-mail: aselakk@eng.pdn.ac.lk \\ Lakshmanakumar Veeraragavan \\ School of Mechanical Engineering, Vellore Institute of Technology \\ Vellore - 632 014, Tamil Nadu, India \\ Email: vtlakshman@gmail.com \\ Mahadharsan Ravichandran \\ School of Mechanical Engineering, Vellore Institute of Technology \\ Vellore - 632 014, Tamil Nadu, India \\ Email: maha.dharsan1999@gmail.com \\ Jayakrishna Kandasamy* \\ School of Mechanical Engineering, Vellore Institute of Technology \\ Vellore - 632 014, Tamil Nadu, India \\ Email: jayakrishna.k@vit.ac.in \\ *Corresponding author \\ https://doi.org/10.46254/j.ieom.20210204
}

ARTICLE INFO

\begin{abstract}
knowledge on sustainability have led to the depletion of raw materials and increased waste generation. Industrial symbiosis now has become a very effective solution and an essential strategy for responsible consumption and waste utilization. This strategy
\end{abstract}

Submitted

Dec 02, 2020

Revised 
helps different organizations to blend their resources, share information, logistics, and waste materials to solve their problems by forming a network to increase profits. This study was directed towards identifying the barriers towards applying Industrial Symbiosis in an organization with probable solutions to them. ISM modeling and MICMAC analysis were used to visualize the impact of different barriers for implementing Industrial symbiosis in an organization and improve efficiency in terms of eco-innovation. The results of this study give experiences and rules to practicing managers in medium and small-scale industries to effectively execute Industrial Symbiosis. The study also adds to the improvement of a basic model for examining the barriers affecting IS with regards to eco-innovation and sustainable frameworks and contributes to ongoing researches on this eco-friendly idea of Industrial Symbiosis.

\section{Introduction}

Sustainable society is achievable through industrial ecological practices, smooth resource circulation through innovative collaborations by industries (Kawanaka et al., 2019). Sustainability is improving living standards not only for current society but also for future generations (Fadhel et al., 2020). Industrial Symbiosis (IS) is a union or partnership among organisations or industries where the waste product of one is used as a raw material for others. It helps to significantly reduce the waste disposal costs as well as raw material costs. This unique idea is one of the keys to reduce wastes and reduce pollution. In IS, the plants are located in such a way that they form a cluster or an ecoinnovation park. This strategy helps in reducing transportation costs. In IS, the driving plants cooperate and develop a synergistic thing or an outcome, and organization trade-offs to accomplish a common forceful lead (Chertow, 2000). (Chertow et al., 2008). Apart from the successful IS in Kalundborg, Denmark (Jacobsen, 2006) now this innovative concept is being adopted by many countries like China (Zhang et al., 2010), Australia (Van Beers et al., 2007), Sweden (Martin and Eklund, 2011) and South Korea (Behera et al., 2012) by developing eco-industrial parks. There is a broad scope of research in this field for its practical implementations. This is a relatively new concept and still in its breeding stage, but if companies adopt this approach, they will be at a profit in both their long-term and short-term goals. Other advantages of getting involved in an IS network include exposure to management structure, decision-making methods, and technical knowledge of other industries (Zhu and Ruth, 2014). Because of the lack of knowledge, industries are not aware of the importance of IS and its benefits ( $\mathrm{Su}$ et al., 2013). As of late, because of the rapid mechanical development and poor asset administration, the utilization of natural assets has been high (Zhe et al., 2016), IS gives a down to earth pathway to address and take care of this issue by shutting the energy and material stream circle (Dong et al., 2013).

IS considers various attributes and forms that can affect the operational practices of a firm (Sakr et al.,2011; Taddeo et al., 2012). The numerous barriers and limitations towards implementing IS network still exists (Tudor et al., 2007; Golev et al., 2014) because of which a few analysts have suggested that the advantages of IS systems can be boosted by enhancement in its plan by utilizing numerical models. Thus, the suitable and effective implementation of IS makes it a debatable subject (Costa and Ferrao, 2010; Posch et al., 2011). Simboli et al., (2014) present that in IS, different firms and governments should try to support each other by compensating each other's losses and sharing profit. (Wu et al., 2017) largely reflect various types of redundancies of IS network and how to establish reliability and stability in IS. (Leigh and Li, 2015) provided helpful insights to develop a cost effective and eco-friendly supply chain that works in such a way that waste from one industry reaches the other within such a time frame that it gets used effectively. Further, Puente et al., (2015) explain the characteristics that improve to the highest chain when the waste from one industry or process becomes an income resource for other industries. Dong et al., (2017) highlight the link among various industries, categorising distinct types of waste and presenting various methods so that they can be utilised efficiently. Bacudio et al., (2016) analysed barriers to the implementation of IS through a quantitative approach. To anchor the upsides of IS, the models have been framed to recognize ideal systems expanding economic advantages ( $\mathrm{Ng}$ et al., 2014), decrease asset utilization (Aviso et al., 2010a), and lessen carbon outflows (Ubando et al., 2014; Yu et al., 2015). The arrangement at that point recognizes the ideal item stream (Gonela and Zhang, 2014), also picks the most proper waste and asset administration choice (Vadenbo et al., 2014), or then again chooses from the accessible energy to waste frameworks (Taskhiri et al., 2014). In this aspect, the study aims to answer the following research questions (RQ).

RQ1: Which barriers have higher significance during the implementation of IS?

RQ2: What is the relationship between these barriers and how they influence each other? 
The primary objective of this examination are -

- To prioritise the barriers towards the implementation of IS.

- To gives industries an overview of the barriers while implementing IS and identify their dependencies.

In this study, interpretive structural modelling (ISM) is utilized to model the barriers affecting the practical implementation of IS in industries. Thirty-three barriers are being distinguished from literature review and opinions of experts from the automotive industry in India. The methodological strides of ISM are being taken after to create a basic model that portrays the dominant barriers that merit consideration. MICMAC investigation has been led to classify the barriers. The result obtained from the study helps decision makers in small-scale industries understand more about the barriers and efficiently implement IS.

\section{Literature review}

Barriers in implementing industrial symbiosis were also analysed using different other techniques. Barriers in implementing IS in an industrial park are analyzed using Decision Making Trial and Evaluation Laboratory (DEMATEL) in (bacudio et al., 2016). In this paper, a systematic design approach is followed for finding the interrelations of barriers. The final results reveal that the strategies must be directed towards the top management. The most correlated barrier of industrial symbiosis is found out as the lack of awareness about mechanism of Industrial Symbiosis. Drivers and barriers of effective industrial materials were analysed and studied by (Pajunen et al., 2012). This paper focused on drivers and barriers for increasing material efficiency by using industrial by-products instead of raw material. The results suggested that the most important barriers for eco-friendly innovations seem to be the cost of investment and the high risk involved in committing capital to unproven technology. Following this, (Pajunen et al., 2013) assessed the political barriers on industrial symbiosis products. The research perspective was both legal and policy instruments. They also identified numerous possible institutional barriers for using industrial residues. An innovative approach to use inter-industrial residues has been framed. Material and energy efficiency, life-cycle and systems thinking are identified as essential elements of this new approach to inter-industrial residues streams and presented using a by-product assessment procedure. Lu et al., (2020) performed case study in china uncovering the benefits of Industrial symbiosis by targeting resource dependent cities. Mallawaarachchi et al., (2020) discussed about the scientific development of industrial symbiosis and provided a lucid overview by performing bibliometric analysis. Patala et al., (2020) discussed the importance of intermediaries to enhance and promote IS activities. Tao et al., (2019) studied the influence of policies on Industrial symbiosis from the perspective of the implementing firm and suggested framework for efficient policy support.

The potential of Industrial Symbiosis and its main and barriers to its implementation is discussed by (neves et al., 2019). This article compiled and analysed literatures according to several factors such as geographic location, type of economic activity, waste/by-products, main benefits, and the methods that focus on potential industrial symbiosis. The results suggested that the there is immense potential for industrial symbiosis throughout the world and especially in Europe. It also listed several key barriers for potential industrial symbiosis and has also given strategies for overcoming the barriers to the realisation of potential Industrial Symbiosis.

Interpretive structural modelling (ISM) is a well-established methodology for identifying relationships among specific items, which define a problem or an issue. This modelling method is used in several barrier analysis literatures. ISM approach is adopted in barrier analysis in implementing sustainable practices by (Raut et al., 2018). In this paper, 14 critical barriers were identified, and the ISM tool was used to establish interrelationship among the identified barriers and to determine the key barriers having high driving power. After analyzing, it was found that six barriers were found to have high influencing power and thus developed model help managers of the organization in understanding importance of the barriers and eliminate them. Likewise, ISM and MICMAC approach combined have always been used in literatures to analyse barriers associated in an application. Barriers in promotion of sustainability through corporate social responsibility in manufacturing industry are discussed by (Bux et al., 2020). The study has been carried out using the ISM-MICMAC approach. The results obtained through the application of ISM and MICMAC signify that the lack of resources, lack of regulations and standards, and lack of policy incentives are the critical barriers for CSR implementation in the manufacturing industry. The usage of ISM MICMAC is not limited to manufacturing sectors. It is widely used in many sectors. Barriers in healthcare services are analysed by (Kumar et al., 2019). This paper focused on identifying the barriers in achieving the quality level in healthcare services. For that purpose, it used ISM and MICMAC for modeling and analysis purpose. The results suggested that most vital barriers are the staff training and the behavioural barriers that needs to be taken into account for an effective healthcare system. 
Vinodh and Asokan (2018) discussed about application of ISM and MICMAC for analysis of Lean Six Sigma barriers. The most dominant barriers that affect Lean Six Sigma adoption with environmental considerations have been identified. Three barriers occupied the base segment of the ISM hierarchy and other five occupied the top level of the ISM hierarchy. This approach serve helpful for managers in removing the key dominant barriers and to enable LSS adoption with environmental considerations easily.

Despite a great deal of research starting at now finished on Modern beneficial interaction starting late, its useful plausibility is sketchy because of the prevailing obstructions. Because of the absence of arranging and upgrading modern advantageous interaction buildings, the development of eco-mechanical parks might be impacted by changes in the associations among the included organizations (Zhang et al., 2014). Likewise, because of the absence of help from the larger amount of administration there is an absence of duty from top positions of administration to apply the idea of modern nature (Chiu and Yong 2004). There is an absence of information of mechanical advantageous interaction wordings and ideas because of the absence of devices to show conceivable partners (Gibbs and Deutz. 2005). The absence of physical and institutional grapples prompts the absence of minimum amount, data, political help, and framework to modern beneficial interaction (Sun et al., 2017). The businesses have an absence of assets to put in innovations and encourage modern beneficial interaction (Chiu and Yong 2004). Mechanical plants do not wish to team up plants to frame union and to adjust to auxiliary changes (Stop et al., 2008). Actualizing modern advantageous interaction requires profound established specialized and hierarchical information which is inadequate with regards to (Dividers and Paquin 2015).

Inspiration between social performing artists is a must to empower modern advantageous interaction effectively at basic levels (URSKA FRIC 2015). There is an absence of new inventive thoughts and methodologies for business tasks, which frustrate mechanical advantageous interaction (URSKA FRIC 2015). Absence of adaptability among the businesses, i.e., their powerlessness to react to sudden changes because of inside and outer elements (URSKA FRIC 2015). Weight from various NGO's, open and natural bodies is not overwhelming to apply mechanical advantageous interaction, i.e., more mindfulness is required. (Rangaswami et al., 2013). Geographic closeness expects a noteworthy activity in constraining costs and impacts of transport and upgrading trust and interest among firms and empowering material exchanges (Tseng and Bui, 2016). The absence of an outsider business framework makes it troublesome for enterprises to build up a system for mechanical beneficial interaction (Tseng and Bui, 2016). After dismantling, there can be some division of parts for reusing, this isn't viewed as per (Chertow et al., 2016). The interest for the items fluctuate which make it hard to produce benefit constantly (Dong et al., 2010). Transportation cost to exchange waste and materials from one industry to other is significantly high (Mutha and Pokharel, 2009). Absence of capacity to prepare individuals in regard to modern beneficial interaction and economical store network (Ashton 2011; Li et al., 2015). Higher experts are insensible towards benevolent strategies (Govindan et al., 2014a, 2014b).

\section{Methodology}

\subsection{ISM- based model}

ISM is an interactive learning process, consisting of a collection of directly and indirectly organized objects ordered in a systematic way. A myriad of factors might be involved in a complicated problem. The understanding of situation or problem obtained from the direct and indirect connections between these factors is greater than the understanding of situation obtained from a single factor. Therefore, the combined understanding of these relationships and discernments are developed through ISM.

The examination was finished utilizing the Interpretative Basic Displaying (ISM), which is utilized to distinguish and abridge the obstructions and their interrelations, primary destinations of ISM are:

- To recognize and rank the factors.

- To build up an interrelationship among the factors.

- To talk about the administrative ramifications of the examination.

ISM is a famous and a demonstrated system for breaking down connections among factors that characterize an issue. ISM is ground-breaking apparatus to accomplish the target when a substantial number of factors are available which might be specifically identified with one another. In such a sort of circumstance, ISM assumes an exceptionally essential job to understand the structure inside the framework. The ISM demonstrates limits down the complex structure inside an issue into a pattern. ISM has been in successive use in the past by numerous scientists because of 
its various advantages. It helps and records the results of social occasion response on complex issues in a capable and considerate way (Attri et al., 2013; Ali and Dubey, 2014; Sushil, 2012, 2009, 2005a, 2005b; Warfield, 1999; Warfield, 1994, 1974). Figure 1 shows the step involved in this study using ISM.

\begin{tabular}{|l|l|}
\hline Step 1 & - Barriers are identified \\
\hline Step 3 & - Interrelation among the barriers is created by the help of experts opinions. \\
\hline Step 4 & - Reachability set is created. \\
\hline Step 5 & - Antecedent set is created. \\
\hline Step 7 & - Level of variables is derived. \\
\hline Step 8 & - Mariables hierarchy is derived. \\
\hline
\end{tabular}

Figure 1. Methodology adopted in this study using ISM

ISM offers various advantages such as, the process is computerized where the algorithm considers all the relations, efficient process by the use of transitivity principle, minimum knowledge of underlying process is required and provides graphical representation of the problem. However, there are limitations or drawbacks to this methodology. The person who is deciding the factors might have prejudice i.e., they might choose or prefer one factor over the another. Thus, the connection established between these factors will be extremely depended on the person's awareness and understanding. The end model will be affected by this prejudice. Adding to this, factors have no weights associated to them. Thus, the chosen factors have no ranking or relatice importance.

\subsection{Barriers identified}

Barriers identified from the literature are organized in the given Table 1. The barriers are picked from the perspective of the usage of modern advantageous interaction in ventures. Table 1 gives 33 distinct barriers picked through the exhaustive investigation of applicable works of writing, eco-advancement, and modern advantageous interaction are deciding variables of these hindrances. These barriers are identified with the help of industrial experts who are major stakeholders in their respective company with extended period of experience (minimum 10 years). Depiction of every boundary is given in Table 1. 
Table 1. Barriers identified through literature review

\begin{tabular}{ll}
\hline S1. No. & Barriers \\
\hline B1 & $\begin{array}{l}\text { Lack of planning and redesigning industrial } \\
\text { symbiosis complexes. }\end{array}$ \\
B2 & $\begin{array}{l}\text { Lack of support from the higher level of } \\
\text { management }\end{array}$
\end{tabular}

\section{Description}

Relevant literature

The growth of eco-industrial parks may be influenced

by changes in the connections among the involved companies. This makes the IS complexes susceptible to change requiring flexible IS complexes

There is an absence of duty from best positions of administration to apply the idea of mechanical environment. Appropriate steps from higher level of management to implement IS increases it chances of getting adopted.

There is an absence of information of mechanical advantageous interaction wordings and ideas because of the absence of instruments to show conceivable partners. Absence of numerous pre-existing IS complexes for others to rely on if uncertainty arises

Absence of eagerness and reaction by mechanical plants to frame partnership and to adjust to auxiliary changes. Coopetition involve investing significant amount of time and capital, which makes it inconvenient

Lack of latest technologies in the industries prevents sustainable by-product exchange and construction of Jacqueline et al (2015) far reaching mechanical advantageous interactions.

There is a lack of funds for industries to install new technologies and facilitate industrial symbiosis and also investment from an individual company will not lead to sustainable Industrial Symbiosis

Physical anchors provide critical mass while institutional anchors provide information, political support, and infrastructure to industrial symbiosis. Instituting these anchors involves a large amount of coordinated efforts between conceivable partners and time.

Lack of efforts from the government to promote industrial symbiosis by regulating the taxes and introducing policies to encourage industrial symbiosis.

Sun et al (2017)

Boons et al (2011) 
There are no prevailing efforts from government to promote IS.

Implementing industrial symbiosis requires deep rooted technical and organizational knowledge which is lacking and since IS is relatively new method, least importance is given to provide proper training.

Motivation between social actors is must to enable industrial symbiosis successfully at primary levels. Lack of effort from these individuals who exercise agency as opposed to constraining social structures offsets the plausible situation.

Lack of flexibility among the industries, i.e. their inability to respond to sudden changes due to internal and external factors. Setting up an separate unit for IS is also seeming unfeasible without the involvement of government

There is a lack of new innovative ideas and approaches for business operations which hinders industrial symbiosis. Wanting of pressure from social influencers prevents the industries from pushing innovation for better business operations.

Due to the high cost of setting up an eco-industrial park, industrial unit of different categories are scattered. Absence of cooperation between industries also acts an important factor that prevents the establishment of parks

Pressure from different NGO's, public and environmental bodies are not heavy to apply industrial symbiosis more awareness is needed. Focus of NGO's on issues that directly influence the environment rather than indirect and chain factors reduces the reach of these niche concepts

Lack of reverse logistics practices which means the reuse of waste materials. High capital, lack of comprehension on rationale of returns and insufficient labour pose a challenge to implement reverse logistic practices.
Judith and Paquin (2015)

URŠKA FRIC (2015)

URŠKA FRIC (2015)

URŠKA FRIC (2015)

Antonina et al (2016)

Ram et al (2013)

Joseph et al (2010)

B15 Lack of reverse logistics practices. 
Sl. No. Barriers

Different short- and long-term goals

Unpredictable return flow of materials

B18 Lack of support from the supplier

B19 Lack of involvement of industries

Lesser demand of green products

Distance between collaborating industries

Lack of institutions to train personnel

\section{Description}

Misalignment of the short-term goals for the instant gains shatters the very idea of the long-term goals. Absence of attention to adjust short and long-haul objectives.

Lack of steady return flow of materials to keep the production rate constant. This uncertainty makes it difficult for the other industries that are in symbiosis with the raw-material proving company to establish a proper supply chain.

Constant supply of fixed quantity of material is challenging for the supplier. Industrial symbiosis relies on suppliers (other industries) for raw materials but due to lack of support it is very inconsistent.

Due to risks and competitions, industries are reluctant to involve in innovative ideas and a circular economy. Lack of research and innovation to produce green products at relatively cheaper price. Absence of coercion from government and impetus prevents the industries from researching new boundaries for the greater good.

Because of the absence of mindfulness, the interest for green items is low; a higher interest will urge ventures to rehearse squander reusing and gain benefits.

Due to lack of clustering of industries, IS is less viable due to higher transportation costs. Presence Eco industrial parks will help offset this barrier but construction of one requires overcoming several interrelated barriers which makes it even difficult

Higher authorities are ignorant towards friendly policies.

Lack of ability to train people in respect to industrial symbiosis and sustainable supply chain. Since, IS is relatively nascent there is no established institution to bring forth experts in IS

Absence of an institutional help for reconciliation, coordination and correspondence.
Relevant literature

Jack et al (2010)

Rizos et al (2016)

Rizos et al (2016)

Rizos et al (2016)

Teh et al (2014)

Teh et al (2014)

Teh et al (2014)

Moktadir et al (2018)

Govindan et al (2015)

Rizos et al (2015) 
Sl. No. Barriers

B26 Long legal procedures

B27

High transportation cost

B28 Varying demands for products

Different product recovery options are not considered

B30 Recycling is not considered

Lack of transparency to develop industria symbiosis

B32 Geographical barriers

B33

\section{Description}

Entangled frameworks and long methods that ventures face to get accreditations, and additionally to meet norms and legitimate commitments.

Transportation cost to transfer waste and materials from one industry to other is relatively high compared to the nominal transportation cost. Adding the uncertainty of input materials further increases the transportation costs.

Supplier can't predict or adjust to the demands as the return material itself id highly unstable. The demand for the products varies which make it difficult to generate profit all the time.

The lack of sustainable recovery options to recover the waste generated. Lack of pressure from masses do encourage companies to overlook sustainability.

After disassembly there can be some fraction of parts for recycling, this is not considered.

Lack of a third-party brokerage system or government agency makes it difficult for industries to develop a network for industrial symbiosis.

Geographic vicinity assumes a key job in limiting expenses and effects of transport.

The enterprises and types of waste products that are processed or reused in their own facilities.
Relevant literature

Ashton. (2011)

Baina et al (2010)

Mutha et al (2009)

Lee et al (2010)

Paksoy et al (2012)

Boons et al (2016)

Tseng et al (2016)

Tseng et al (2016) 


\subsection{Building up the Structural Self-Interaction Matrix (SSIM)}

After the obstructions are distinguished through the writing survey, a logical relationship is formed between the boundaries as for the sets of the hindrances. The connections among the boundaries were analysed through the reactions recorded through a poll, the poll was sent to the business specialists and later tried for the legitimacy of substance. The reactions were recorded and broke down for the development of a basic structural self-interaction matrix (SSIM). For creating structural self-interaction matrix (SSIM) in Table 2, the given symbols have been used to imply the course of associations between elements (i and $\mathrm{j}$ ):

- V: i prompt j however j does not prompt $\mathrm{i}$.

- A: i don't prompt j yet j prompt i.

- $\quad \mathrm{X}$ : j prompt i and i prompt j.

- $\mathrm{O}: \mathrm{j}$ and $\mathrm{i}$ are irrelevant to one another.

\subsection{Building the reachability matrix}

The SSIM has been changed over into a twofold system, i.e., the reachability network (Table 3) by substituting V, A, X and O by 1 and 0 . The substitutions of '1' and ' 0 ' is done as given below:

- In the event that the $(i, j)$ passage in the SSIM is $V$, at that point the $(i, j)$ section in the reachability grid moves toward becoming ' 1 ' and $(j, i)$ passage progresses toward becoming ' 0 '.

- In the event that the (i,j) passage in the SSIM is $A$, at that point the $(i, j)$ section in the reachability grid moves toward becoming ' 0 ' and $(j, i)$ passage progresses toward becoming ' 1 '.

- In the event that the $(i, j)$ passage in the SSIM is $X$, at that point the $(i, j)$ section in the reachability grid moves toward becoming ' 1 ' and $(j, i)$ passage likewise moves toward becoming ' 1 '.

- In the event that the $(i, j)$ passage in the SSIM is $\mathrm{O}$, at that point the $(\mathrm{i}, \mathrm{j})$ section in the reachability lattice moves toward becoming ' 0 ' and $(\mathrm{j}, \mathrm{i})$ passage likewise progresses toward becoming ' 0 '.

\subsection{Transitivity principle}

After the underlying reachability framework is inferred, the idea of transitivity is presented with the goal that a portion of the cells of the underlying reachability lattice are filled by surmising. Transitivity can be clarified with the accompanying precedent if component ' $i$ ' identifies with component ' $j$ ' and component ' $j$ ' identifies with component ' $k$ ', at that point transitivity infers component 'i' identifies with component ' $k$ '. It helps in keeping up the theoretical consistency. The last reachability grid will then comprise of a few sections from the match insightful examinations and some deduced passages. The transitivity idea is utilized to fill the hole assuming any.

Transitivity is the essential suspicion in ISM and is constantly utilized in this demonstrating approach (Watson, 1978; Sharma et al., 1995; Sushil, 2005a, 2005b). Following the above guidelines, the underlying reachability grid is readied. In the wake of consolidating the transitivity idea as depicted over, the last reachability grid is gotten in Table 4. 


\subsection{Level Partitioning}

From the last reachability matrix in Table 4, the reachability set and the antecedent set for each barrier chosen is found. The reachability set includes the barrier itself and others which the barrier might help to achieve (barrier B1 helps in the overcoming barriers B1, B4, B10, B11, B14, B17, B19, B25, B27, B33) The antecedent set comprises of the barrier itself and other barriers which help in achieving it (barriers B1, B5, B7, B10, B11, B16, B18, B19, B23, B24, B25, B26, B27, B29, B30, B32 helps in overcoming barrier B1). After this, the intersection set is obtained for all the barriers. The last reachability framework acquired in Table 4 is divided into various levels. After the main emphasis, the variable ordered to level 1 are disposed of and the parcelling method is rehashed on the staying variable to decide the level 2 . These cycles are proceeded until the point that the level of every factor has been resolved. The outcomes for cycles 1 to 8 are outlined in Table 5 .

\subsection{Digraph}

From the final reachability matrix and levelling of barriers, the fundamental model is made by techniques for centres and lines of edges. In case there is an association between the barriers $j$ and $i$, this is showed up by an arrow which demonstrates from $i$ to $j$. The derived ISM model is represented in Figure 2 also knowns as digraph or directed graph. 
Table 2. Structural self-interaction matrix

\begin{tabular}{|c|c|c|c|c|c|c|c|c|c|c|c|c|c|c|c|c|c|c|c|c|c|c|c|c|c|c|c|c|c|c|c|c|}
\hline & $\begin{array}{l}\text { B } \\
32\end{array}$ & $\begin{array}{l}\text { B } \\
31\end{array}$ & $\begin{array}{l}\text { B } \\
\mathbf{3 0}\end{array}$ & $\begin{array}{l}\text { B } \\
29\end{array}$ & $\begin{array}{l}\text { B } \\
28\end{array}$ & $\begin{array}{l}\text { B } \\
27\end{array}$ & $\begin{array}{l}\text { B } \\
26\end{array}$ & $\begin{array}{l}\text { B } \\
25\end{array}$ & $\begin{array}{l}\text { B } \\
24\end{array}$ & $\begin{array}{l}\text { B } \\
23\end{array}$ & $\begin{array}{l}\text { B } \\
22\end{array}$ & $\begin{array}{l}\text { B } \\
21\end{array}$ & $\begin{array}{l}\text { B } \\
20\end{array}$ & $\begin{array}{l}\text { B } \\
19\end{array}$ & $\begin{array}{l}\text { B } \\
18\end{array}$ & $\begin{array}{l}\text { B } \\
17\end{array}$ & $\begin{array}{l}\text { B } \\
16\end{array}$ & $\begin{array}{l}\text { B } \\
15\end{array}$ & $\begin{array}{l}\text { B } \\
14\end{array}$ & $\begin{array}{l}\text { B } \\
13\end{array}$ & $\begin{array}{l}\text { B } \\
12\end{array}$ & $\begin{array}{l}\text { B } \\
11\end{array}$ & $\begin{array}{l}\text { B } \\
10\end{array}$ & $\begin{array}{l}\text { B } \\
9\end{array}$ & $\begin{array}{l}\text { B } \\
8\end{array}$ & $\begin{array}{l}\text { B } \\
7\end{array}$ & $\begin{array}{l}\text { B } \\
6\end{array}$ & $\begin{array}{l}\text { B } \\
5\end{array}$ & $\begin{array}{l}\text { B } \\
4\end{array}$ & $\begin{array}{l}\text { B } \\
\mathbf{3}\end{array}$ & $\begin{array}{l}\text { B } \\
2\end{array}$ & $\begin{array}{l}\mathbf{B} \\
1\end{array}$ \\
\hline B1 & $\mathrm{V}$ & $\mathrm{A}$ & $\mathrm{O}$ & $\mathrm{A}$ & A & $\mathrm{O}$ & $\mathrm{V}$ & $\mathrm{A}$ & $\mathrm{V}$ & $\mathrm{A}$ & A & $\mathrm{O}$ & $\mathrm{O}$ & $\mathrm{O}$ & $\mathrm{V}$ & $\mathrm{A}$ & $\mathrm{V}$ & $\mathrm{A}$ & $\mathrm{O}$ & $\mathrm{V}$ & $\mathrm{O}$ & $\mathrm{O}$ & $\mathrm{V}$ & $\mathrm{V}$ & $\mathrm{O}$ & $\mathrm{O}$ & $\mathrm{A}$ & $\mathrm{O}$ & $\mathrm{A}$ & $\mathrm{V}$ & $\mathrm{O}$ & $\mathrm{O}$ \\
\hline B2 & $\mathrm{O}$ & $\mathrm{O}$ & A & A & $\mathrm{V}$ & $\mathrm{V}$ & A & A & A & $\mathrm{O}$ & A & $\mathrm{O}$ & $\mathrm{O}$ & $\mathrm{O}$ & A & $\mathrm{O}$ & $\mathrm{O}$ & $\mathrm{V}$ & A & $\mathrm{V}$ & $\mathrm{V}$ & $\mathrm{V}$ & A & A & $\mathrm{O}$ & A & $\mathrm{O}$ & $\mathrm{V}$ & $\mathrm{V}$ & $\mathrm{V}$ & A & \\
\hline B3 & A & $\mathrm{V}$ & A & A & A & $\mathrm{O}$ & $\mathrm{O}$ & $\mathrm{V}$ & A & A & $\mathrm{V}$ & $\mathrm{O}$ & $\mathrm{O}$ & $\mathrm{V}$ & $\mathrm{V}$ & $\mathrm{V}$ & $\mathrm{V}$ & $\mathrm{O}$ & $\mathrm{O}$ & $\mathrm{V}$ & $\mathrm{O}$ & $\mathrm{O}$ & A & A & A & A & $\mathrm{V}$ & A & A & $\mathrm{O}$ & & \\
\hline B4 & $\mathrm{O}$ & $\mathrm{O}$ & A & A & A & A & $\mathrm{O}$ & A & $\mathrm{O}$ & $\mathrm{O}$ & $\mathrm{V}$ & $\mathrm{O}$ & $\mathrm{V}$ & A & A & $\mathrm{V}$ & $\mathrm{V}$ & $\mathrm{V}$ & $\mathrm{V}$ & $\mathrm{O}$ & $\mathrm{O}$ & $\mathrm{O}$ & A & $\mathrm{O}$ & A & $\mathrm{V}$ & $\mathrm{O}$ & A & $\mathrm{V}$ & & & \\
\hline B5 & $\mathrm{V}$ & $\mathrm{V}$ & A & $\mathrm{V}$ & $\mathrm{V}$ & $\mathrm{O}$ & $\mathrm{V}$ & V & A & $\mathrm{O}$ & A & $\mathrm{V}$ & $\mathrm{V}$ & $\mathrm{V}$ & A & A & $\mathrm{V}$ & $\mathrm{O}$ & A & $\mathrm{V}$ & $\mathrm{V}$ & $\mathrm{O}$ & $\mathrm{V}$ & $\mathrm{O}$ & $\mathrm{V}$ & A & A & $\mathrm{V}$ & & & & \\
\hline B6 & $\mathrm{V}$ & A & $\mathrm{V}$ & $\mathrm{V}$ & $\mathrm{V}$ & $\mathrm{V}$ & A & $\mathrm{V}$ & $\mathrm{V}$ & $\mathrm{O}$ & $\mathrm{V}$ & A & $\mathrm{V}$ & A & $\mathrm{O}$ & $\mathrm{O}$ & A & $\mathrm{V}$ & $\mathrm{O}$ & A & $\mathrm{V}$ & A & A & $\mathrm{V}$ & A & A & $\mathrm{O}$ & & & & & \\
\hline B7 & $\mathrm{V}$ & $\mathrm{O}$ & $\mathrm{O}$ & A & $\mathrm{V}$ & $\mathrm{O}$ & $\mathrm{O}$ & A & $\mathrm{V}$ & $\mathrm{O}$ & $\mathrm{O}$ & $\mathrm{O}$ & A & A & A & $\mathrm{O}$ & $\mathrm{V}$ & $\mathrm{V}$ & $\mathrm{V}$ & A & $\mathrm{O}$ & $\mathrm{V}$ & $\mathrm{A}$ & $\mathrm{O}$ & $\mathrm{V}$ & $\mathrm{V}$ & & & & & & \\
\hline B8 & A & A & $\mathrm{O}$ & $\mathrm{V}$ & $\mathrm{O}$ & A & $\mathrm{V}$ & A & A & A & A & $\mathrm{V}$ & $\mathrm{V}$ & A & $\mathrm{V}$ & A & $\mathrm{O}$ & $\mathrm{O}$ & A & $\mathrm{V}$ & $\mathrm{V}$ & $\mathrm{V}$ & $\mathrm{V}$ & $\mathrm{V}$ & $\mathrm{V}$ & & & & & & & \\
\hline B9 & $\mathrm{O}$ & $\mathrm{V}$ & A & $\mathrm{O}$ & $\mathrm{O}$ & $\mathrm{O}$ & $\mathrm{O}$ & A & $\mathrm{O}$ & $\mathrm{V}$ & $\mathrm{O}$ & $\mathrm{O}$ & A & $\mathrm{O}$ & $\mathrm{O}$ & $\mathrm{V}$ & $\mathrm{V}$ & $\mathrm{O}$ & A & A & $\mathrm{O}$ & $\mathrm{V}$ & A & $\mathrm{O}$ & & & & & & & & \\
\hline B10 & A & A & $\mathrm{O}$ & A & $\mathrm{V}$ & A & $\mathrm{V}$ & V & A & $\mathrm{V}$ & A & $\mathrm{V}$ & $\mathrm{O}$ & $\mathrm{O}$ & $\mathrm{V}$ & $\mathrm{O}$ & V & A & A & A & $\mathrm{V}$ & $\mathrm{O}$ & $\mathrm{O}$ & & & & & & & & & \\
\hline B11 & $\mathrm{V}$ & $\mathrm{O}$ & A & $\mathrm{V}$ & $\mathrm{O}$ & $\mathrm{V}$ & A & V & $\mathrm{O}$ & $\mathrm{O}$ & A & $\mathrm{O}$ & $\mathrm{O}$ & $\mathrm{O}$ & $\mathrm{O}$ & A & $\mathrm{O}$ & A & A & $\mathrm{O}$ & $\mathrm{O}$ & $\mathrm{O}$ & & & & & & & & & & \\
\hline B12 & A & $\mathrm{V}$ & $\mathrm{O}$ & A & A & $\mathrm{O}$ & A & $\mathrm{O}$ & A & $\mathrm{V}$ & A & A & $\mathrm{O}$ & $\mathrm{V}$ & $\mathrm{V}$ & A & A & $\mathrm{O}$ & A & $\mathrm{O}$ & $\mathrm{V}$ & & & & & & & & & & & \\
\hline B13 & A & A & $\mathrm{O}$ & $\mathrm{V}$ & $\mathrm{V}$ & $\mathrm{V}$ & $\mathrm{O}$ & A & $\mathrm{O}$ & $\mathrm{V}$ & A & $\mathrm{O}$ & $\mathrm{O}$ & $\mathrm{O}$ & $\mathrm{O}$ & A & A & $\mathrm{O}$ & A & $\mathrm{O}$ & & & & & & & & & & & & \\
\hline B14 & A & $\mathrm{O}$ & $\mathrm{O}$ & $\mathrm{O}$ & A & $\mathrm{V}$ & A & V & $\mathrm{V}$ & A & $\mathrm{V}$ & $\mathrm{O}$ & A & A & $\mathrm{O}$ & A & $\mathrm{V}$ & $\mathrm{V}$ & A & & & & & & & & & & & & & \\
\hline B15 & A & A & $\mathrm{V}$ & $\mathrm{V}$ & A & $\mathrm{O}$ & $\mathrm{V}$ & A & A & $\mathrm{O}$ & A & A & $\mathrm{O}$ & $\mathrm{O}$ & $\mathrm{O}$ & $\mathrm{V}$ & $\mathrm{O}$ & A & & & & & & & & & & & & & & \\
\hline B16 & $\mathrm{V}$ & $\mathrm{V}$ & $\mathrm{V}$ & $\mathrm{V}$ & $\mathrm{V}$ & A & $\mathrm{O}$ & $\mathrm{O}$ & $\mathrm{O}$ & $\mathrm{O}$ & $\mathrm{O}$ & $\mathrm{O}$ & $\mathrm{O}$ & $\mathrm{V}$ & $\mathrm{V}$ & $\mathrm{V}$ & $\mathrm{V}$ & & & & & & & & & & & & & & & \\
\hline B17 & $\mathrm{V}$ & A & A & A & A & $\mathrm{O}$ & A & A & A & A & $\mathrm{V}$ & $\mathrm{V}$ & $\mathrm{O}$ & A & $\mathrm{O}$ & $\mathrm{O}$ & & & & & & & & & & & & & & & & \\
\hline B18 & $\mathrm{V}$ & $\mathrm{O}$ & $\mathrm{V}$ & $\mathrm{O}$ & $\mathrm{O}$ & $\mathrm{V}$ & $\mathrm{O}$ & V & $\mathrm{V}$ & A & $\mathrm{V}$ & A & $\mathrm{V}$ & A & A & & & & & & & & & & & & & & & & & \\
\hline B19 & $\mathrm{O}$ & $\mathrm{O}$ & $\mathrm{V}$ & $\mathrm{O}$ & $\mathrm{V}$ & $\mathrm{O}$ & $\mathrm{O}$ & A & A & $\mathrm{O}$ & $\mathrm{V}$ & $\mathrm{V}$ & $\mathrm{V}$ & A & & & & & & & & & & & & & & & & & & \\
\hline B20 & A & $\mathrm{V}$ & $\mathrm{V}$ & $\mathrm{O}$ & A & A & $\mathrm{O}$ & $\mathrm{O}$ & A & $\mathrm{O}$ & $\mathrm{O}$ & $\mathrm{V}$ & A & & & & & & & & & & & & & & & & & & & \\
\hline B21 & $\mathrm{V}$ & $\mathrm{O}$ & $\mathrm{O}$ & $\mathrm{O}$ & A & $\mathrm{V}$ & $\mathrm{O}$ & $\mathrm{O}$ & $\mathrm{O}$ & $\mathrm{O}$ & A & $\mathrm{V}$ & & & & & & & & & & & & & & & & & & & & \\
\hline B22 & $\mathrm{O}$ & A & $\mathrm{O}$ & $\mathrm{V}$ & $\mathrm{V}$ & $\mathrm{O}$ & A & $\mathrm{V}$ & $\mathrm{O}$ & $\mathrm{V}$ & A & & & & & & & & & & & & & & & & & & & & & \\
\hline B23 & $\mathrm{V}$ & $\mathrm{V}$ & $\mathrm{V}$ & A & A & $\mathrm{V}$ & A & $\mathrm{O}$ & A & $\mathrm{V}$ & & & & & & & & & & & & & & & & & & & & & & \\
\hline B24 & $\mathrm{V}$ & $\mathrm{V}$ & A & $\mathrm{O}$ & $\mathrm{O}$ & A & $\mathrm{V}$ & $\mathrm{V}$ & A & & & & & & & & & & & & & & & & & & & & & & & \\
\hline B25 & $\mathrm{O}$ & A & $\mathrm{V}$ & $\mathrm{V}$ & $\mathrm{V}$ & A & A & A & & & & & & & & & & & & & & & & & & & & & & & & \\
\hline B26 & $\mathrm{O}$ & A & A & A & $\mathrm{V}$ & $\mathrm{V}$ & A & & & & & & & & & & & & & & & & & & & & & & & & & \\
\hline B27 & $\mathrm{O}$ & $\mathrm{O}$ & $\mathrm{O}$ & A & A & A & & & & & & & & & & & & & & & & & & & & & & & & & & \\
\hline B28 & $\mathrm{O}$ & $\mathrm{V}$ & $\mathrm{V}$ & $\mathrm{O}$ & A & & & & & & & & & & & & & & & & & & & & & & & & & & & \\
\hline B29 & $\mathrm{O}$ & $\mathrm{V}$ & A & $\mathrm{V}$ & & & & & & & & & & & & & & & & & & & & & & & & & & & & \\
\hline B30 & A & $\mathrm{O}$ & $\mathrm{V}$ & & & & & & & & & & & & & & & & & & & & & & & & & & & & & \\
\hline B31 & A & A & & & & & & & & & & & & & & & & & & & & & & & & & & & & & & \\
\hline B32 & $\mathrm{V}$ & & & & & & & & & & & & & & & & & & & & & & & & & & & & & & & \\
\hline B33 & & & & & & & & & & & & & & & & & & & & & & & & & & & & & & & & \\
\hline
\end{tabular}


Table 3. Initial Reachability Matrix

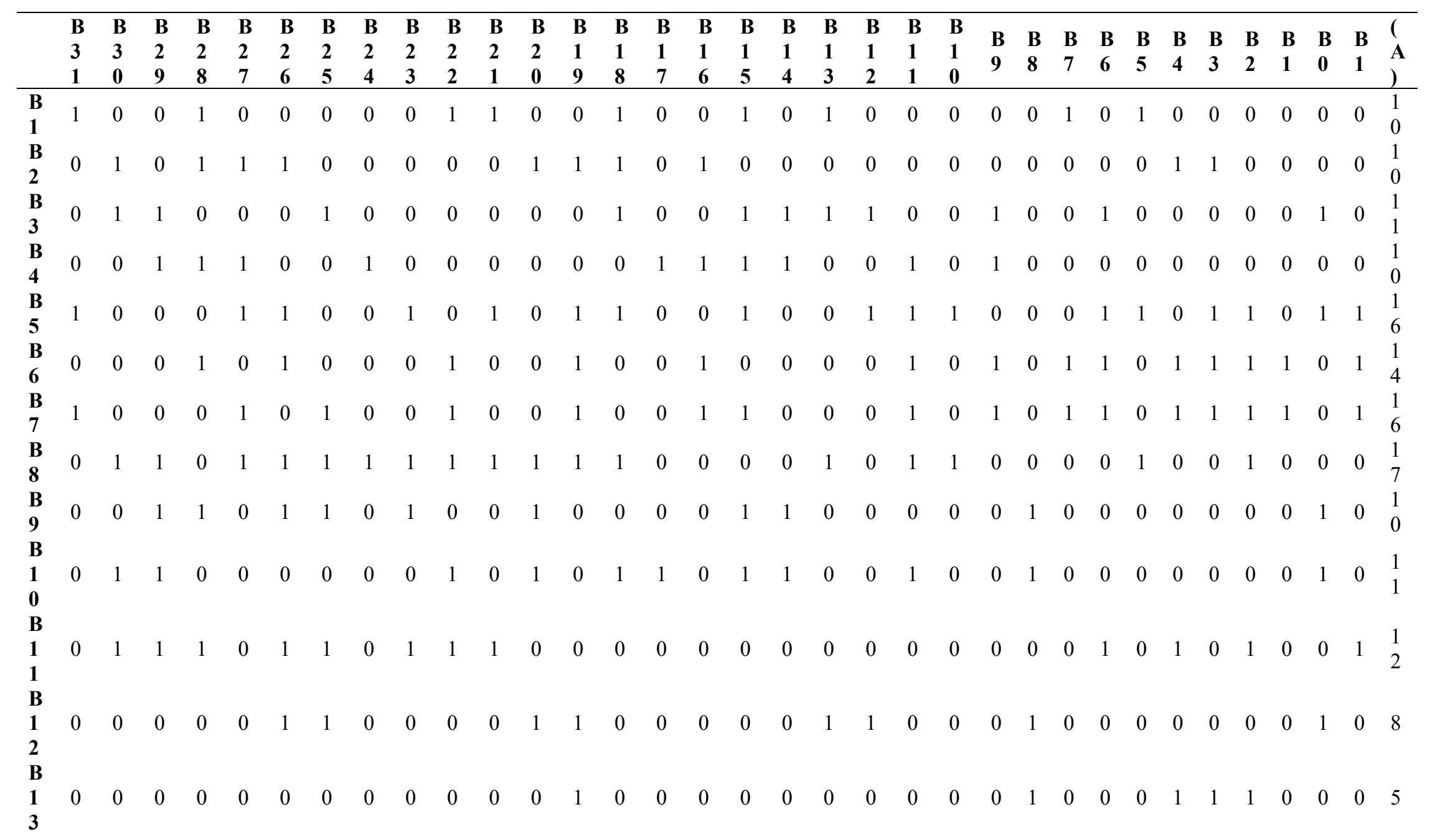




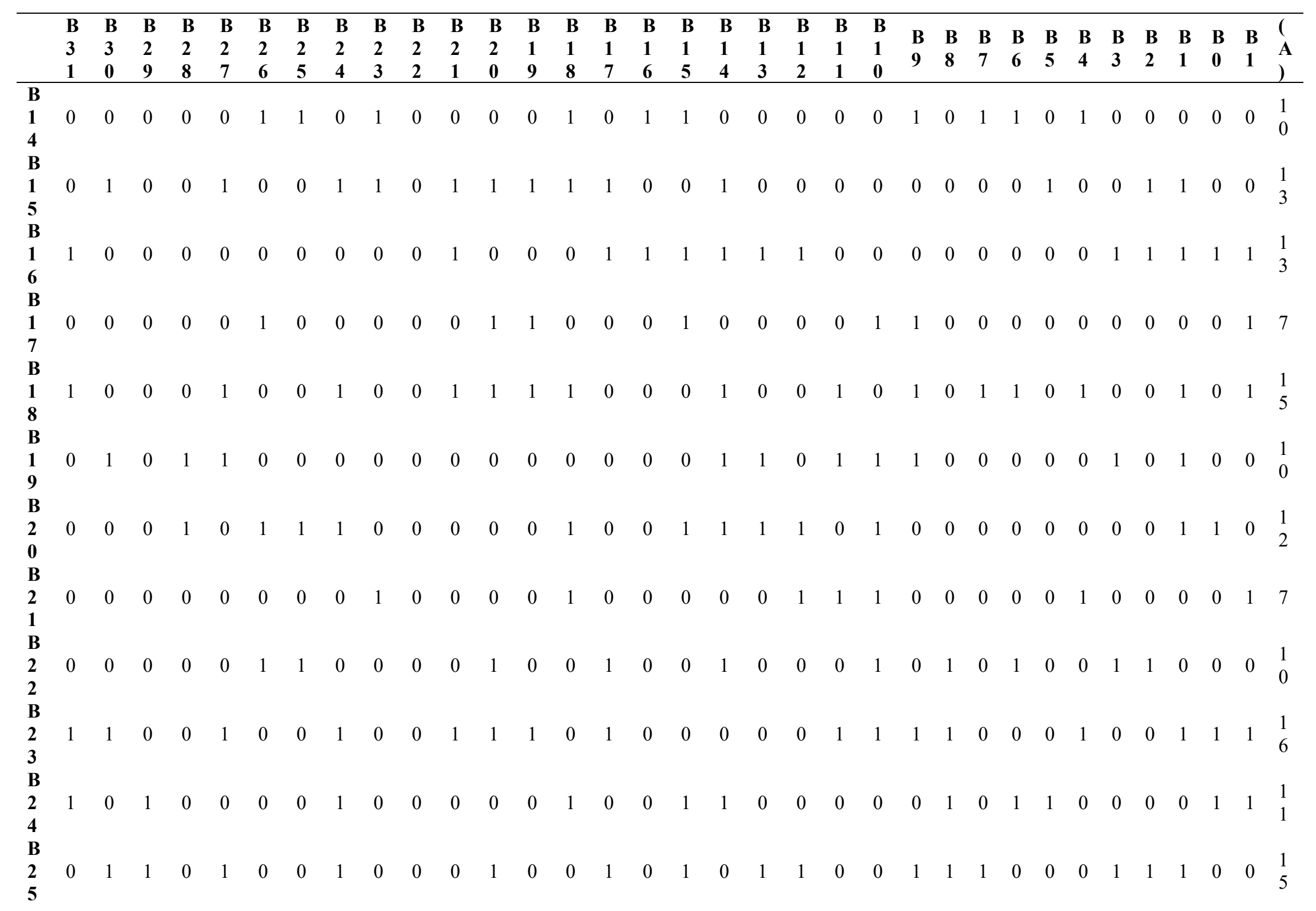




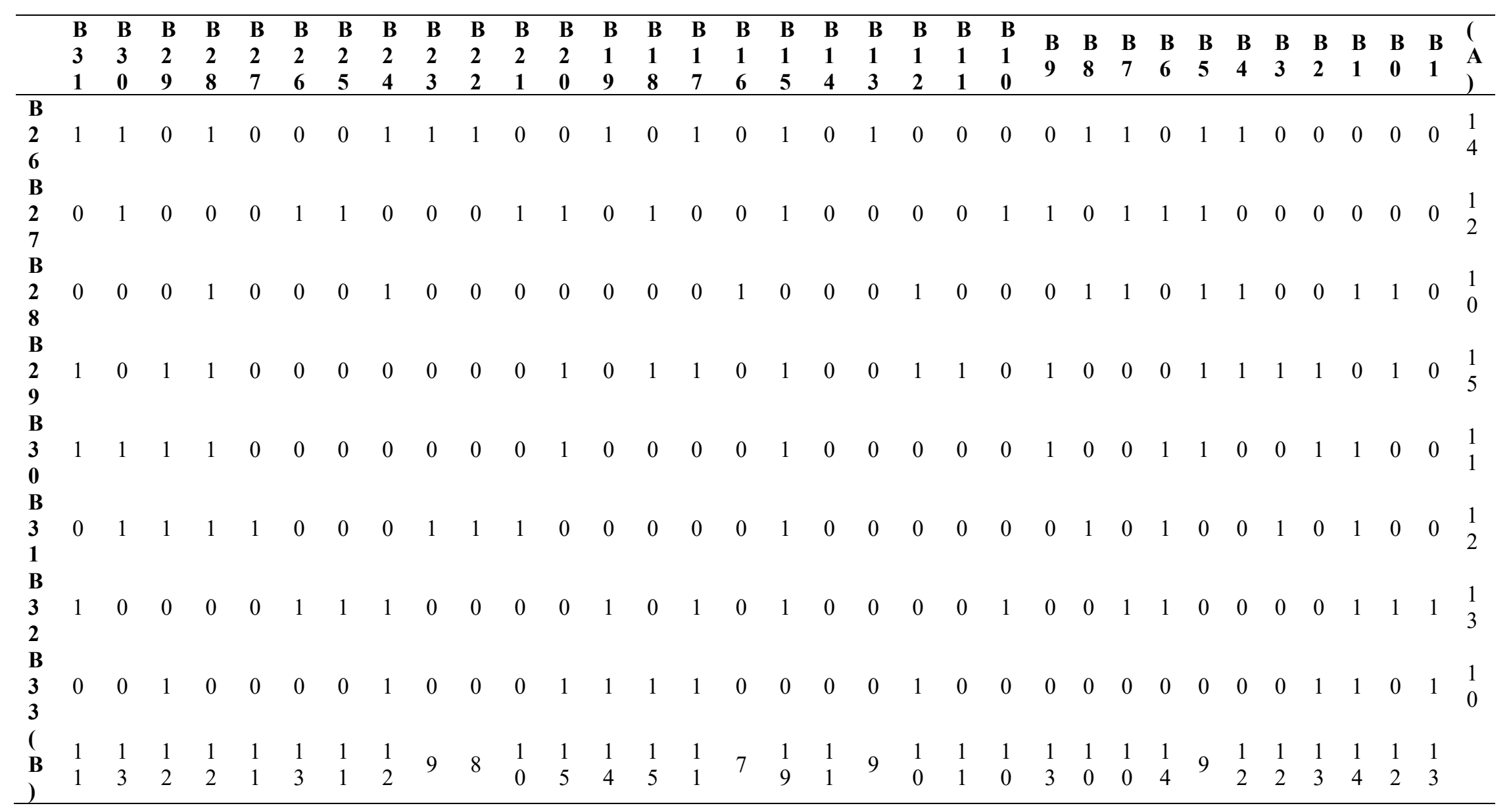

Table 4. Final Reachability Matrix

\begin{tabular}{|c|c|c|c|c|c|c|c|c|c|c|c|c|c|c|c|c|c|c|c|c|c|c|c|c|c|c|c|c|c|c|c|c|c|}
\hline & $\begin{array}{l}\text { B } \\
\mathbf{3} \\
\mathbf{1}\end{array}$ & $\begin{array}{l}\text { B } \\
\mathbf{3} \\
\mathbf{0}\end{array}$ & $\begin{array}{l}\text { B } \\
2 \\
9\end{array}$ & $\begin{array}{l}\text { B } \\
2 \\
8\end{array}$ & $\begin{array}{l}\text { B } \\
2 \\
7\end{array}$ & $\begin{array}{l}\text { B } \\
2 \\
6\end{array}$ & $\begin{array}{l}\text { B } \\
2 \\
5\end{array}$ & $\begin{array}{l}\text { B } \\
2 \\
4\end{array}$ & $\begin{array}{l}\text { B } \\
2 \\
3\end{array}$ & $\begin{array}{l}\text { B } \\
2 \\
2\end{array}$ & $\begin{array}{l}\text { B } \\
2 \\
1\end{array}$ & $\begin{array}{l}\text { B } \\
2 \\
0\end{array}$ & $\begin{array}{l}\text { B } \\
1\end{array}$ & $\begin{array}{l}\text { B } \\
1 \\
8\end{array}$ & $\begin{array}{l}\text { B } \\
1\end{array}$ & $\begin{array}{l}\text { B } \\
1\end{array}$ & $\begin{array}{l}\text { B } \\
1 \\
5\end{array}$ & $\begin{array}{l}\text { B } \\
1\end{array}$ & $\begin{array}{l}\text { B } \\
1 \\
3\end{array}$ & $\begin{array}{l}\text { B } \\
1 \\
2\end{array}$ & $\begin{array}{l}\text { B } \\
1 \\
1\end{array}$ & $\begin{array}{l}\text { B } \\
\mathbf{1} \\
\mathbf{0}\end{array}$ & $\begin{array}{l}\text { B } \\
9\end{array}$ & $\begin{array}{l}\text { B } \\
8\end{array}$ & $\begin{array}{l}\text { B } \\
7\end{array}$ & $\begin{array}{l}\text { B } \\
6\end{array}$ & $\begin{array}{l}\text { B } \\
5\end{array}$ & $\begin{array}{l}\text { B } \\
4\end{array}$ & $\begin{array}{l}\text { B } \\
\mathbf{3}\end{array}$ & $\begin{array}{l}\text { B } \\
2\end{array}$ & $\begin{array}{l}\text { B } \\
1\end{array}$ & $\begin{array}{l}\text { B } \\
\mathbf{0}\end{array}$ & $\begin{array}{l}\text { B } \\
1\end{array}$ \\
\hline & 1 & 0 & 0 & 1 & 1 & 0 & 1 & 0 & 0 & 1 & 1 & 0 & 0 & 1 & $\mathbf{0}$ & * & 1 & $\begin{array}{l}1 \\
*\end{array}$ & 1 & 0 & $\mathbf{0}$ & 0 & $\begin{array}{l}1 \\
*\end{array}$ & $\begin{array}{l}1 \\
*\end{array}$ & 1 & $\begin{array}{ll}1 & 1\end{array}$ & 1 & 0 & 1 & 1 & 0 & $\begin{array}{l}1 \\
*\end{array}$ & 0 \\
\hline
\end{tabular}




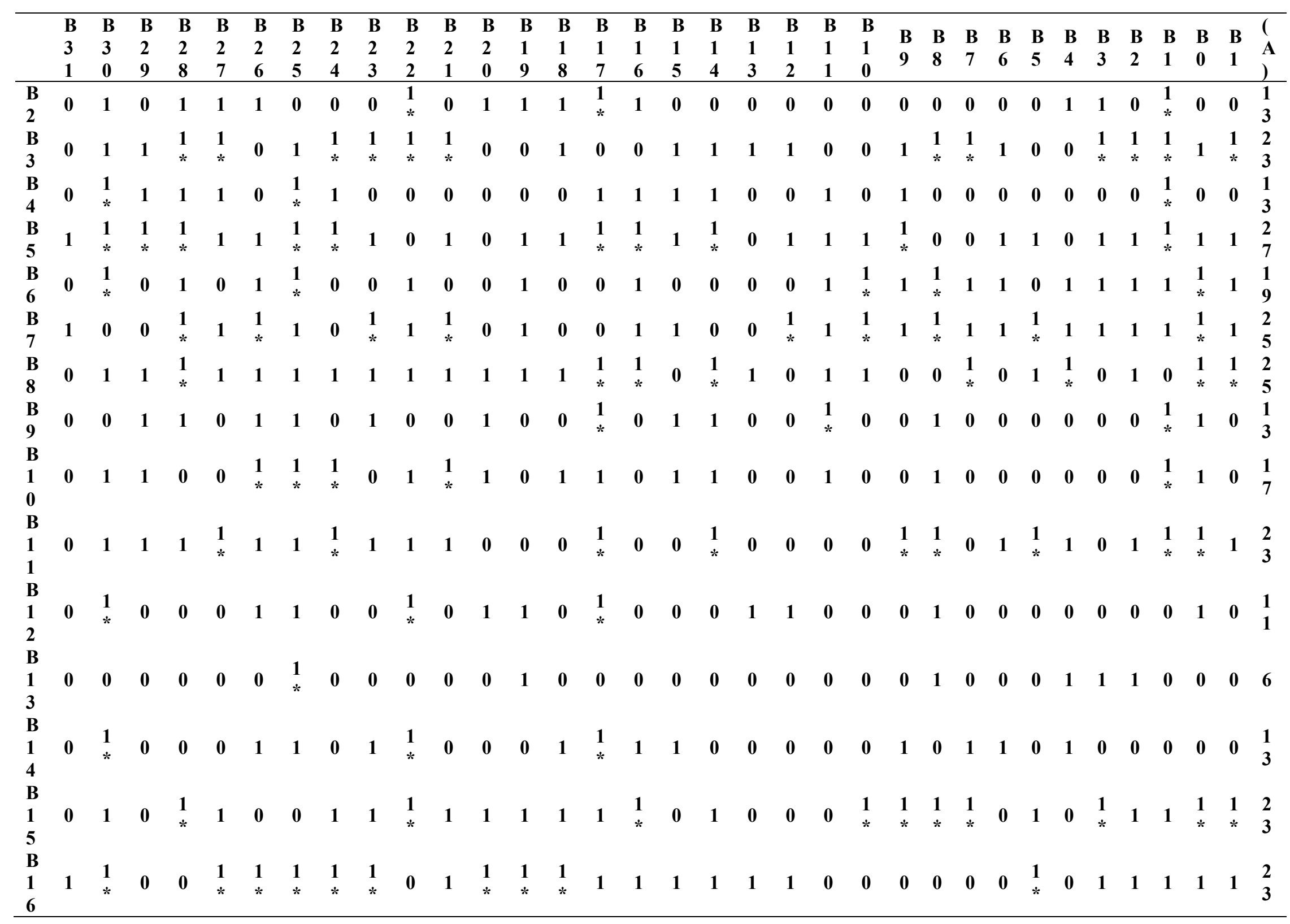




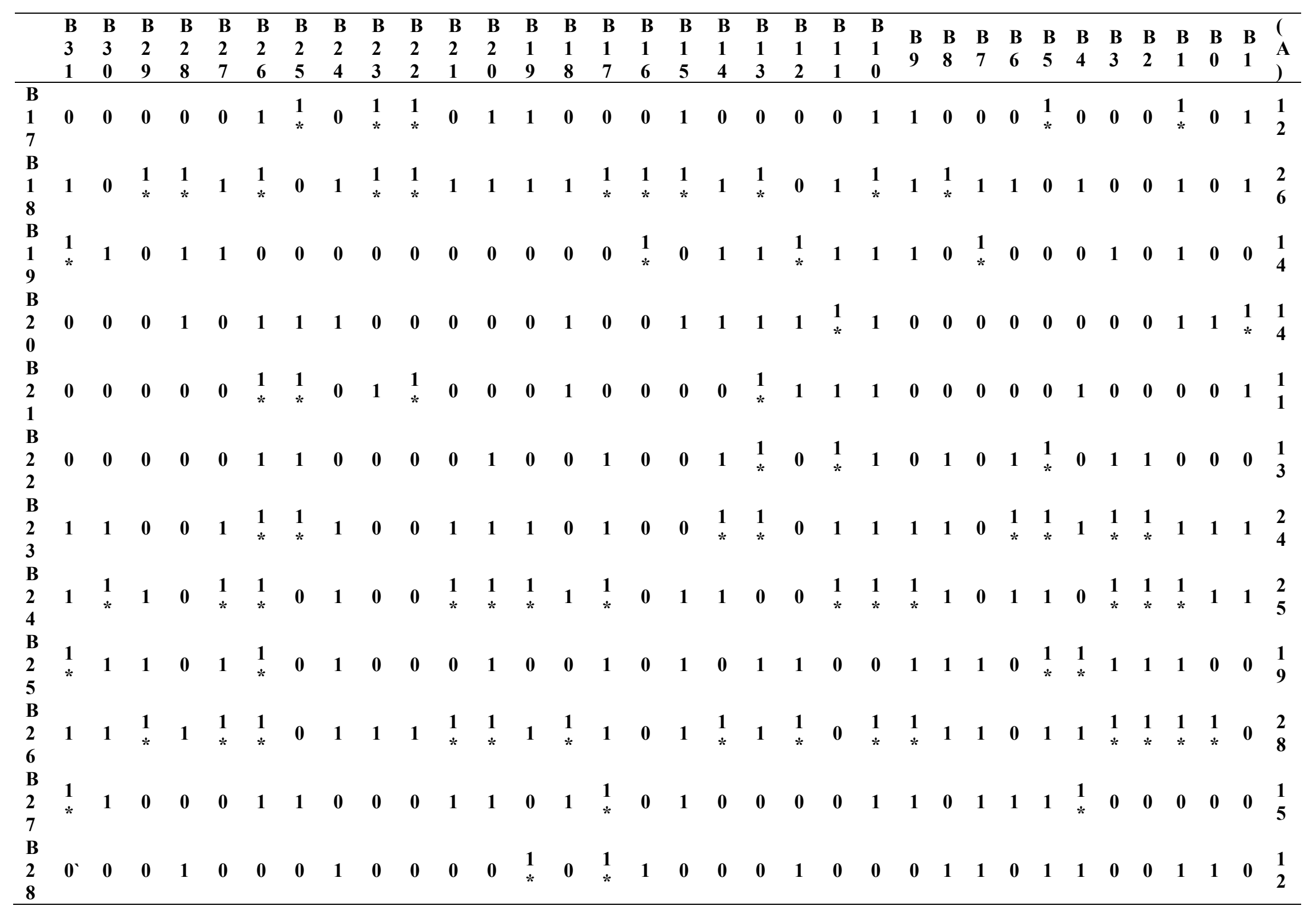




\begin{tabular}{|c|c|c|c|c|c|c|c|c|c|c|c|c|c|c|c|c|c|c|c|c|c|c|c|c|c|c|c|c|c|c|c|c|c|c|}
\hline & $\begin{array}{l}\text { B } \\
\mathbf{3} \\
\mathbf{1} \\
\end{array}$ & $\begin{array}{l}\text { B } \\
\mathbf{3} \\
\mathbf{0}\end{array}$ & $\begin{array}{l}\text { B } \\
2 \\
9\end{array}$ & $\begin{array}{l}\text { B } \\
2 \\
8\end{array}$ & $\begin{array}{l}\text { B } \\
2 \\
7\end{array}$ & $\begin{array}{l}\text { B } \\
2 \\
6\end{array}$ & $\begin{array}{l}\text { B } \\
2 \\
5\end{array}$ & $\begin{array}{l}B \\
2 \\
4\end{array}$ & $\begin{array}{l}\mathbf{B} \\
2 \\
3\end{array}$ & $\begin{array}{l}\text { B } \\
2 \\
2\end{array}$ & $\begin{array}{l}\text { B } \\
2 \\
1\end{array}$ & $\begin{array}{l}\text { B } \\
2 \\
0\end{array}$ & $\begin{array}{l}\text { B } \\
1 \\
9\end{array}$ & $\begin{array}{l}\text { B } \\
1 \\
8\end{array}$ & $\begin{array}{l}\mathbf{B} \\
\mathbf{1} \\
7\end{array}$ & $\begin{array}{l}\text { B } \\
1 \\
6\end{array}$ & $\begin{array}{l}\text { B } \\
1 \\
5\end{array}$ & $\begin{array}{l}\text { B } \\
1 \\
4\end{array}$ & $\begin{array}{l}\mathbf{B} \\
\mathbf{1} \\
\mathbf{3}\end{array}$ & $\begin{array}{l}\mathbf{B} \\
1 \\
2\end{array}$ & $\begin{array}{l}\mathbf{B} \\
\mathbf{1} \\
\mathbf{1}\end{array}$ & $\begin{array}{l}\text { B } \\
\mathbf{1} \\
\mathbf{0}\end{array}$ & $\begin{array}{l}\text { B } \\
9\end{array}$ & $\begin{array}{l}\text { B } \\
8\end{array}$ & $\begin{array}{l}\text { B } \\
7\end{array}$ & $\begin{array}{l}\text { B } \\
6\end{array}$ & $\begin{array}{l}\text { B } \\
5\end{array}$ & $\begin{array}{l}\text { B } \\
4\end{array}$ & $\begin{array}{l}\text { B } \\
\mathbf{3}\end{array}$ & $\begin{array}{l}\text { B } \\
2\end{array}$ & $\begin{array}{l}\text { B } \\
1\end{array}$ & $\begin{array}{l}\text { B } \\
\mathbf{0}\end{array}$ & $\begin{array}{l}\text { B } \\
1\end{array}$ & $\begin{array}{l}\text { ( } \\
\text { A }\end{array}$ \\
\hline $\begin{array}{l}\text { B } \\
2 \\
9\end{array}$ & 1 & 0 & 1 & 1 & $\mathbf{0}$ & 0 & $\mathbf{0}$ & $\begin{array}{l}1 \\
*\end{array}$ & $\mathbf{0}$ & $\mathbf{0}$ & $\mathbf{0}$ & 1 & $\begin{array}{l}1 \\
*\end{array}$ & 1 & 1 & $\begin{array}{l}1 \\
*\end{array}$ & 1 & $\mathbf{0}$ & $\mathbf{0}$ & 1 & 1 & $\mathbf{0}$ & 1 & $\begin{array}{l}1 \\
*\end{array}$ & $\begin{array}{l}1 \\
*\end{array}$ & $\mathbf{0}$ & 1 & 1 & 1 & 1 & $\mathbf{0}$ & 1 & $\mathbf{0}$ & $\begin{array}{l}2 \\
0\end{array}$ \\
\hline $\begin{array}{l}\text { B } \\
\mathbf{3} \\
\mathbf{0}\end{array}$ & 1 & 1 & 1 & 1 & 0 & 0 & 0 & $\begin{array}{l}1 \\
*\end{array}$ & 0 & $\mathbf{0}$ & $\mathbf{0}$ & 1 & $\begin{array}{l}1 \\
*\end{array}$ & $\begin{array}{l}1 \\
*\end{array}$ & $\begin{array}{l}1 \\
*\end{array}$ & $\begin{array}{l}1 \\
*\end{array}$ & 1 & $\mathbf{0}$ & $\mathbf{0}$ & $\begin{array}{l}1 \\
*\end{array}$ & $\begin{array}{l}1 \\
*\end{array}$ & $\mathbf{0}$ & 1 & $\begin{array}{l}1 \\
*\end{array}$ & $\begin{array}{l}1 \\
*\end{array}$ & 1 & 1 & $\begin{array}{l}1 \\
*\end{array}$ & $\begin{array}{l}1 \\
*\end{array}$ & 1 & 1 & $\mathbf{0}$ & $\mathbf{0}$ & $\begin{array}{l}2 \\
2\end{array}$ \\
\hline $\begin{array}{l}\text { B } \\
\mathbf{3} \\
\mathbf{1}\end{array}$ & $\mathbf{0}$ & 1 & 1 & 1 & 1 & $\begin{array}{l}1 \\
*\end{array}$ & 0 & $\mathbf{0}$ & 1 & 1 & 1 & $\mathbf{0}$ & $\mathbf{0}$ & $\mathbf{0}$ & $\begin{array}{l}1 \\
*\end{array}$ & $\begin{array}{l}1 \\
*\end{array}$ & 1 & $\begin{array}{l}1 \\
*\end{array}$ & $\begin{array}{l}1 \\
*\end{array}$ & $\mathbf{0}$ & 0 & $\mathbf{0}$ & $\mathbf{0}$ & 1 & $\begin{array}{l}1 \\
*\end{array}$ & 1 & $\mathbf{0}$ & $\begin{array}{l}1 \\
*\end{array}$ & 1 & $\mathbf{0}$ & 1 & $\mathbf{0}$ & $\begin{array}{l}1 \\
*\end{array}$ & $\begin{array}{l}2 \\
0\end{array}$ \\
\hline $\begin{array}{l}\text { B } \\
3 \\
2\end{array}$ & 1 & $\begin{array}{l}1 \\
*\end{array}$ & $\begin{array}{l}1 \\
*\end{array}$ & $\begin{array}{l}1 \\
*\end{array}$ & $\begin{array}{l}1 \\
*\end{array}$ & 1 & 1 & 1 & $\begin{array}{l}1 \\
*\end{array}$ & $\begin{array}{l}1 \\
*\end{array}$ & $\begin{array}{l}1 \\
*\end{array}$ & 0 & 1 & 0 & 1 & 0 & 1 & $\mathbf{0}$ & $\mathbf{0}$ & $\mathbf{0}$ & 0 & 1 & $\mathbf{0}$ & $\begin{array}{l}1 \\
*\end{array}$ & 1 & 1 & $\mathbf{0}$ & $\begin{array}{l}1 \\
*\end{array}$ & $\begin{array}{l}1 \\
*\end{array}$ & $\begin{array}{l}1 \\
*\end{array}$ & 1 & 1 & 1 & $\begin{array}{l}2 \\
4\end{array}$ \\
\hline $\begin{array}{l}\text { B } \\
\mathbf{3} \\
\mathbf{3}\end{array}$ & 0 & $\mathbf{0}$ & 1 & $\mathbf{0}$ & $\mathbf{0}$ & $\begin{array}{l}1 \\
*\end{array}$ & 0 & 1 & $\mathbf{0}$ & $\mathbf{0}$ & 0 & 1 & 1 & 1 & 1 & 0 & 0 & $\mathbf{0}$ & 0 & 1 & $\begin{array}{l}1 \\
*\end{array}$ & $\mathbf{0}$ & 0 & $\mathbf{0}$ & $\mathbf{0}$ & $\mathbf{0}$ & 0 & 0 & 0 & 1 & 1 & 0 & 1 & $\begin{array}{l}1 \\
2\end{array}$ \\
\hline $\begin{array}{l}\text { ( } \\
\mathbf{B}\end{array}$ & 1 & 2 & 1 & 2 & 1 & 2 & 2 & 1 & 1 & 1 & 1 & 1 & 1 & 1 & 2 & 1 & 2 & 1 & 1 & 1 & 1 & 1 & 1 & 2 & 1 & 1 & 1 & 1 & 1 & 1 & 2 & 1 & 1 & \\
\hline D & 6 & 1 & 6 & 0 & 8 & 4 & 2 & 9 & 5 & 7 & 6 & 9 & 9 & 8 & 4 & 7 & 0 & 4 & 4 & 5 & 7 & 6 & 9 & 1 & 7 & 6 & 7 & 9 & 9 & 9 & 4 & 8 & 8 & \\
\hline
\end{tabular}

Table 5. Ranking of barriers

\begin{tabular}{lllll}
\hline Barrier no. & Reachability set & Antecedent set & Intersection set & Level \\
\hline B1 & $1,4,10,11,14,17,19,25,27,33$ & $1,5,7,10,11,16,18,19,23,24,25,26,27,29,30,32$ & $1,10,11,19,25,27$ \\
B2 & $2,4,5,6,12,13,14,16,28,29$ & $2,3,4,5,6,8,10,11,12,14,15,16,19,23,24,25,26,27$ & $2,4,5,6,12,14,16$ \\
B3 & $2,3,7,14,17,18,19,20,23,26,32$ & $3,31,32$ & V & II \\
B4 & $3,4,5,8,15,16,17,18,21,23$ & $3,4,5,8,9,10,11,18,24,25,26,29,30,31,32,33$ & $3,18,24,26,32$ & VII \\
& & $1,2,3,4,5,6,7,8,9,11,15,18,19,20,26,28,29,30,31$, & $3,4,5,8,15,18$ & V
\end{tabular}




\begin{tabular}{|c|c|c|c|c|}
\hline Barrier no. & Reachability set & Antecedent set & Intersection set & Level \\
\hline B5 & $\begin{array}{l}1,3,4,5,6,8,9,11,13,14,15,16,17,18,20,21,22,23, \\
26,27,29,30,32,33\end{array}$ & $1,2,3,4,5,7,8,11,15,16,18,19,23,24,25,26,31,32$ & $1,3,4,5,8,11,15,16,18,23,26,32$ & VI \\
\hline B6 & $6,10,13,16,21,23,25,26,28,29,30,31,33$ & $\begin{array}{l}2,5,6,7,8,9,10,11,12,14,16,17,18,20,21,22,23,24 \\
, 25,26,27,31,32,33\end{array}$ & $6,10,16,21,23,25,26,31,33$ & II \\
\hline B7 & $3,7,8,9,11,12,14,20,22,23,24,27,32$ & $\begin{array}{l}1,3,4,5,6,7,8,9,10,11,12,13,14,16,17,20,21,22,2 \\
3,26,27,32\end{array}$ & $3,7,8,11,23,27,32$ & $\mathrm{~V}$ \\
\hline B8 & $2,3,5,6,7,8,9,10,11,12,13,14,19,21,22,17,30$ & $\begin{array}{l}3,4,5,8,10,11,15,16,18,20,23,24,25,26,28,29,30 \\
32,33\end{array}$ & $3,5,8,10,11,30$ & VII \\
\hline B9 & $3,4,6,7,9,12,17,18,24,32$ & $3,5,7,8,9,11,14,15,16,17,18,21,26,31,32$ & $3,7,9,17,18,32$ & IV \\
\hline $\mathrm{B} 10$ & $2,3,10,12,14,15,17,18,21,24,32$ & $1,2,3,6,7,8,10,11,12,14,15,17,18,21,26,31,32$ & $2,3,10,12,14,15,17,18,21,32$ & II \\
\hline B11 & $2,3,4,6,7,9,10,11,26,28,30,33$ & $1,3,5,7,8,10,11,15,16,18,23,24,26,27,31,32$ & $3,7,10,11,26$ & IV \\
\hline $\mathrm{B} 12$ & $6,7,12,13,19,20,24,32$ & $\begin{array}{l}2,7,8,9,10,12,15,16,17,18,19,22,23,24,25,26,27 \\
29,30,33\end{array}$ & $7,12,19,24$ & VI \\
\hline B13 & $13,24,28,29,30$ & $\begin{array}{l}2,5,6,7,8,12,13,15,16,17,18,23,24,26,28,29,30,3 \\
2,33\end{array}$ & $13,24,28,29,30$ & I \\
\hline B14 & $6,7,9,14,16,17,23,25,26,28$ & $\begin{array}{l}1,2,3,5,8,10,14,15,16,18,20,21,24,26,27,29,30,3 \\
3\end{array}$ & $14,16,26$ & VII \\
\hline B15 & $2,5,8,9,11,12,13,14,15,18,27,30,31$ & $\begin{array}{l}2,4,5,8,9,10,11,12,14,15,16,18,22,23,24,25,26,2 \\
7,28,29,30,31,32,33\end{array}$ & $\begin{array}{l}2,5,8,9,11,12,24,14,15,18,27,29,30,3 \\
1\end{array}$ & II \\
\hline B16 & $\begin{array}{l}1,2,5,8,9,11,12,13,14,15,16,17,18,19,20,27,29,3 \\
0,31,32,33\end{array}$ & $1,2,4,5,6,7,8,11,14,15,16,18,19,28,29,30,31$ & $1,2,5,8,11,14,15,16,18,19,29,30,31$ & VI \\
\hline B17 & $6,12,13,17,22,23,33$ & $\begin{array}{l}1,3,4,5,7,9,10,14,16,17,18,20,24,25,26,27,29,30 \\
, 31,32\end{array}$ & 17 & IV \\
\hline B18 & $\begin{array}{l}1,5,6,8,11,12,13,14,17,18,21,22,23,25,26,28,31 \\
33\end{array}$ & $\begin{array}{l}1,3,4,5,8,9,10,11,15,16,18,19,20,22,23,24,25,26 \\
, 31\end{array}$ & $1,5,8,11,18,20,22,23,25,26,31$ & $\mathrm{~V}$ \\
\hline B19 & $2,4,5,18,19,21,22,23,29,31$ & $1,3,8,12,16,18,19,20,21,22,23,25,26,31$ & $18,19,21,22,23,31$ & III \\
\hline B20 & $4,6,7,8,14,17,18,19,20,22,31,32$ & $3,5,7,12,16,18,19,20,21,25,26,28,29,30,33$ & $7,18,19,20$ & VI \\
\hline B21 & $9,14,20,21,22,28,33$ & $4,5,6,7,8,9,10,18,19,20,21,22,23,24,29,30,33$ & $9,20,21,22,33$ & III \\
\hline B22 & $6,7,12,15,18,22,24,26,29,30$ & $5,6,7,8,15,17,18,19,20,21,22,23,24,26,27,32$ & $6,7,15,18,22,24,26$ & IV \\
\hline B23 & $\begin{array}{l}1,2,5,6,7,8,11,12,13,15,18,21,22,23,24,26,28,29 \\
, 30,31,32,33\end{array}$ & $\begin{array}{l}1,3,4,5,6,7,11,14,15,17,18,19,23,24,25,26,27,29 \\
, 30\end{array}$ & $1,5,6,7,11,15,18,23,24,26,29,30$ & VI \\
\hline
\end{tabular}




\begin{tabular}{|c|c|c|c|c|}
\hline Barrier no. & Reachability set & Antecedent set & Intersection set & Level \\
\hline B24 & $\begin{array}{l}1,2,3,5,6,7,8,11,12,13,14,15,17,18,21,22,23,24 \\
26,27,28,29,30,31,32,33\end{array}$ & $\begin{array}{l}1,3,6,7,9,10,11,12,13,15,18,22,23,24,25,26,28,2 \\
9,30,31,32\end{array}$ & $\begin{array}{l}1,3,6,7,11,12,13,15,18,22,23,24,26,2 \\
8,29,30,31,32\end{array}$ & VI \\
\hline $\mathrm{B} 25$ & $2,3,5,8,12,15,17,19,20,23,24,25,29,30,31$ & $1,3,6,7,8,14,15,18,19,25,26,27,28,29,30,31,32$ & $3,8,15,19,25,29,30,31$ & $\mathrm{~V}$ \\
\hline B26 & $\begin{array}{l}1,2,3,4,5,8,9,10,12,13,15,17,19,20,23,24,25,26 \\
28,29,30,31\end{array}$ & $1,3,5,6,7,11,14,18,22,23,24,26,27,30,31,32$ & $1,3,5,23,24,26,30,31$ & VIII \\
\hline $\mathrm{B} 27$ & $2,6,7,11,12,14,17,22,23,25,26,27$ & $1,5,7,8,11,15,16,17,22,23,24,25,26,27,28,29,30$ & $7,11,17,22,23,25,26,27$ & III \\
\hline B28 & $4,8,16,20,24,25,27,28,31,32$ & $\begin{array}{l}2,6,7,8,11,13,14,18,21,23,24,25,26,27,28,29,30, \\
31,32\end{array}$ & $8,24,25,27,28,31,32$ & $\mathrm{~V}$ \\
\hline B29 & $\begin{array}{l}1,3,4,8,12,14,15,16,17,20,21,23,24,25,27,28,29, \\
30,32\end{array}$ & $\begin{array}{l}1,2,3,5,6,7,13,15,16,19,22,23,24,25,26,29,30,31 \\
, 32\end{array}$ & $1,3,15,16,23,24,25,29,30,32$ & VI \\
\hline $\mathrm{B} 30$ & $\begin{array}{l}1,2,3,4,8,12,14,15,16,17,20,21,23,24,25,26,27,2 \\
8,29,30,31,32\end{array}$ & $\begin{array}{l}1,3,5,6,7,8,11,13,15,16,22,23,24,25,26,29,30,32 \\
, 33\end{array}$ & $1,3,8,15,16,23,24,25,26,29,30$ & VII \\
\hline B31 & $2,3,4,5,9,10,11,17,24,26,29,31$ & $\begin{array}{l}2,3,4,5,6,7,9,10,11,15,16,17,18,19,20,23,24,25 \\
26,28,30,31,32,33\end{array}$ & $2,3,4,5,9,10,11,17,24,26,31$ & II \\
\hline B32 & $\begin{array}{l}1,2,3,4,5,6,7,8,9,10,11,13,15,17,22,24,25,28,29, \\
31,32,33\end{array}$ & $1,3,5,6,7,8,9,10,11,12,15,16,20,23,24,28,29,32$ & $1,3,5,6,7,8,9,10,11,15,24,26,29,32$ & VI \\
\hline B33 & $3,8,12,13,14,15,20,30,31,33$ & $1,3,5,6,7,8,11,15,16,17,18,20,21,23,24,31,32,33$ & $3,8,15,20,31,33$ & III \\
\hline
\end{tabular}




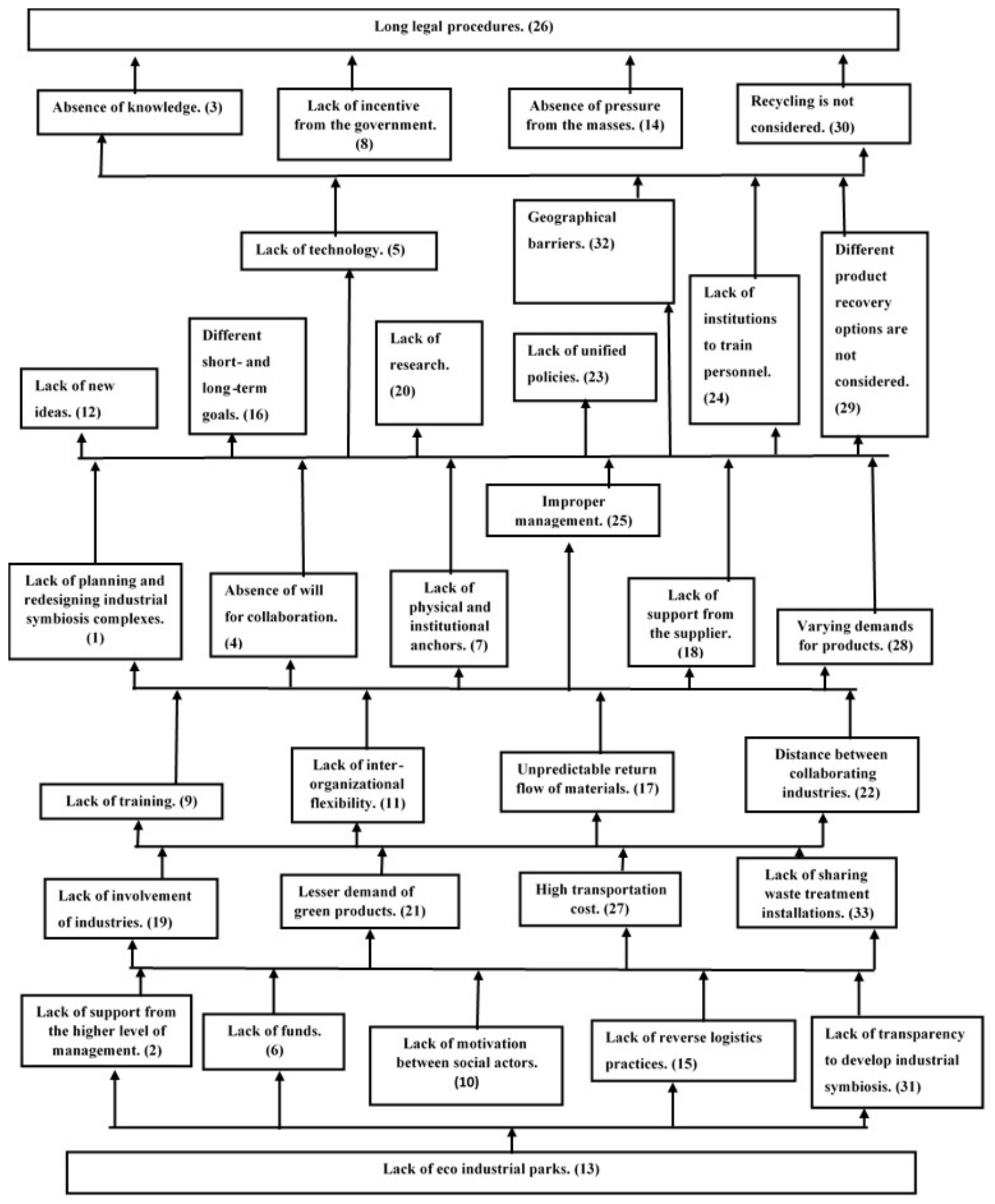

Figure 2. Digraph 


\subsection{MICMAC Analysis}

Matriced'Impacts croises-multipication appliqué and clasment (cross-impact matrix multiplication applied to classification) is abbreviated as MICMAC. The motive of employing MICMAC is to gauge the dependence and driving power(s) of the identified barrier. This examination is utilized to segregate the chosen barriers and aggregate them into four categories, namely: driving factors, dependence factors, autonomous factors and linkage factors. Table 6 shows final reachability matrix obtained. In MICMAC, factors are classified in four quadrants as given below in Figure 3.

Table 6. Position coordinates of distinguished factors

\begin{tabular}{lll}
\hline Variables & Dependence Power (A) & Driving Power (B) \\
\hline 1 & 16 & 20 \\
2 & 21 & 13 \\
3 & 16 & 23 \\
4 & 20 & 13 \\
5 & 18 & 27 \\
6 & 24 & 19 \\
7 & 22 & 25 \\
8 & 19 & 25 \\
9 & 15 & 13 \\
10 & 17 & 17 \\
11 & 16 & 23 \\
12 & 19 & 11 \\
13 & 19 & 6 \\
14 & 18 & 13 \\
15 & 24 & 23 \\
16 & 17 & 23 \\
17 & 20 & 12 \\
18 & 14 & 26 \\
19 & 14 & 14 \\
20 & 15 & 14 \\
21 & 17 & 11 \\
22 & 16 & 13 \\
23 & 19 & 24 \\
24 & 21 & 25 \\
25 & 17 & 19 \\
26 & 16 & 28 \\
27 & 17 & 15 \\
28 & 19 & 12 \\
29 & 19 & 20 \\
30 & 19 & 22 \\
31 & 24 & 20 \\
32 & 18 & 24 \\
33 & 18 & \\
& &
\end{tabular}




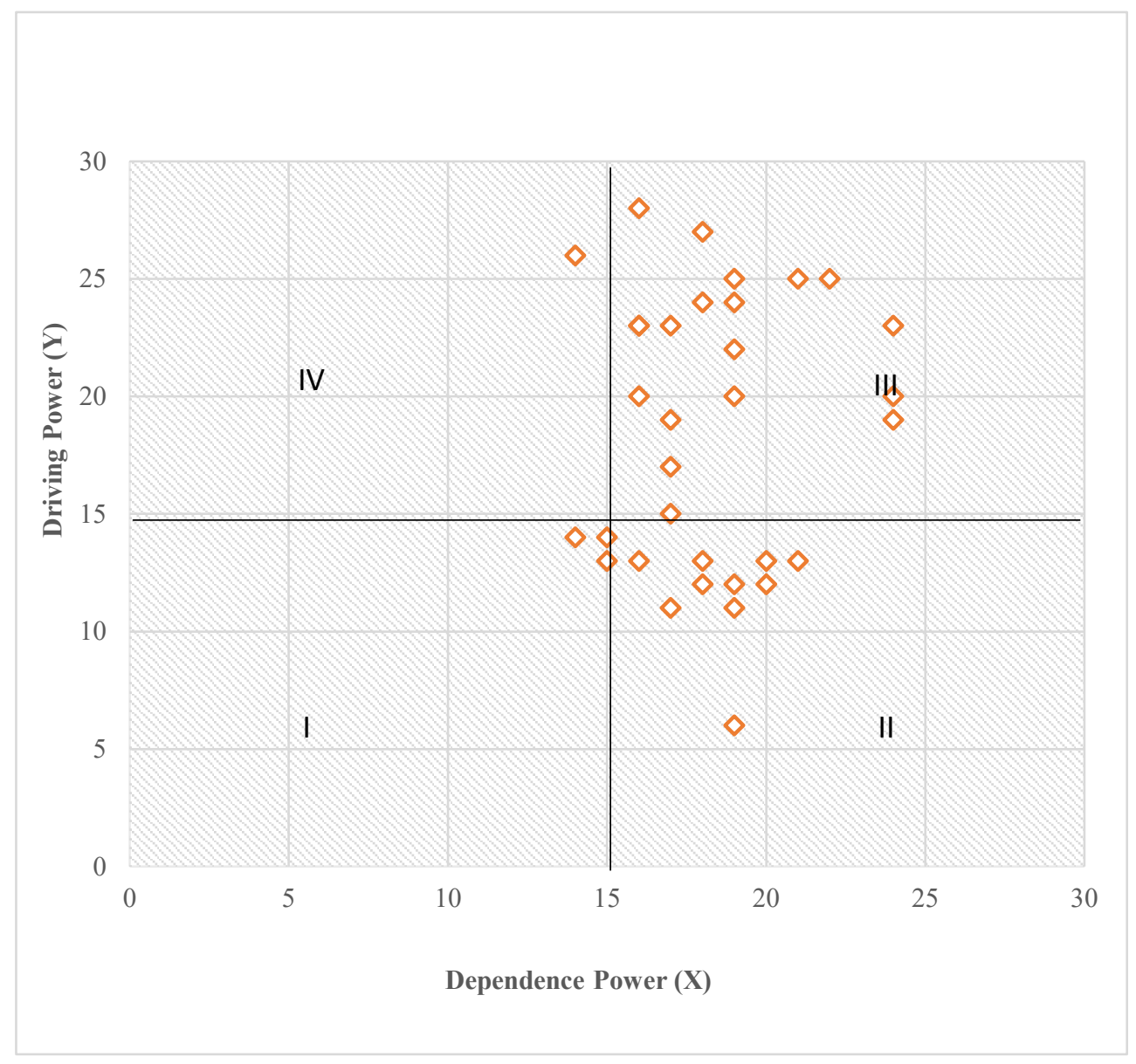

Figure 3. Dependence and driving power diagram

\section{Results and discussions}

The main objective of this research is to prioritise the barriers towards the implementation of IS by establishing interdependencies among the barriers and to give industries an overview of the barriers while implementing IS by analysing the driving and dependencies of these barriers. In order to achieve these objectives, ISM - based model and MICMAC analysis is utilized. The established dependencies between these barriers helps the management to make better decisions. All the below mentioned observations are obtained from Dependence and driving power diagram, Figure 3.

The barrier in the quadrant 1 is called autonomous barriers and these factors have a feeble drive control and frail reliance control. In this quadrant, we have three factors like lack of training (B9), lack of involvement of industries (B19), and lack of research (B20). These barriers are less important since they do not have high driving and reliance control. Lack of training leads to unfamiliarity with industrial symbiosis concepts in several aspects such as technical and organizational expertise. Bacudioa et al (2016) categorized The results of this study differs with the findings for Bacudioa et al (2016) as lack of training was categorized as an effect barrier in a study conducted in industrial park in the Philippines. Similarly, the lack of innovation is regarded as an effect of lack of commitment from top management.

Quadrant 2: Dependence factors - These factors have a frail drive control, however solid reliance control. In this quadrant, we have 11 factors which are, lack of sharing waste treatment installations (B33), varying demands for products (B28), high transportation cost (B27), distance between collaborating industries (B22), lesser demand of green products (B21), unpredictable return flow of materials (B17), absence of pressure from the masses (B14), lack of eco-industrial parks (B13), lack of new ideas (B12), absence of will for collaboration (B4) and lack of support from the higher level of management (B2). In earlier studies, the absence of will for collaboration is seen as an effect barrier as similar to the finding of this study. The higher distance between collaborating industries highly influences higher transportation cost. On the other hand, the Kosmol and Otto (2020) identified lack of demand for green products as an important market 
related barrier. These solid reliance control indicates that, these barriers need all the other barriers to come together in order to increase their effect on successful implementation of IS i.e., their success is highly dependent on the success of the other barriers.

Quadrant 3: Linkage factors - These factors have a solid drive control and additionally solid reliance control. In this quadrant, we have 18 factors which are geographical barriers (B32), lack of transparency to develop IS (B31), recycling is not considered (B30), different product recovery options are not considered (B29), long legal procedures (B26), improper management (B25), lack of institutions to train personnel (B24), lack of unified policies (B23), different short and long term goals (B16), lack of reverse logistics practices (B15), lack of inter-organizational flexibility (B11), lack of motivation between social actors (B10), lack of incentive from the government (B8), lack of physical and institutional anchors (B7), lack of funds (B6), lack of technology (B5), absence of knowledge (B3) and lack of planning and redesigning IS complexes (B1). A large portion of the barriers fall under these categories. Since they have both solid driving and reliance control any change occurring to these barriers will hinder the process to overcome other barriers and also have a feedback on themselves. These are highly volatile barriers that might affect the successful implementation of IS. It can also be observed from Figure 2 that most these have barriers occupy higher position. Thus, more importance must be given to these barriers while implementing IS to have a successful endeavour.

Quadrant 4: Driving factors -These factors have a solid drive control, however frail reliance control. In this quadrant we only have one factor, i.e., lack of support from the supplier (B18). Since this barrier has solid drive control, it can have extreme effects on other barriers. In earlier studies, the barriers like lack of trust, lack of funding and lack of policy were categorised as cause barriers. However, the lack of support from supplier will have the similar effect on implementation of industrial symbiosis. They must be addressed more carefully and may be treated as principal cause of all other barriers.

\section{Implication of the research}

The drivers engaged with the execution of IS for the firm under examination present extensive difficulties for the administration of firm. This examination has been created to dissect the relationship among the barriers towards practical implementation of IS in industries. It can likewise go about as a manual for the top administration to choose the strategy in the effective execution of IS to reduce the waste as well as raw material cost and increase the profit as well as productivity, this study will help in the development of eco-industrial parks which can act as an IS model. In this study, the barriers are distinguished from literature review and automotive experts in India. The model developed can be applied to other developing countries for better decision making, since the scenarios are same.

The implications that can be interpreted from this study are as follows:

1. This study will aid the management in deciding which barrier to prioritise based on their level and also offer a better understanding of the chosen barriers

2. ISM model establishes the order in which the steps must be taken by the decision makers for successful deployment of IS. MICMAC analysis indicates the set of barriers that needs to addressed by the decisionmakers based on their driving and reliance control.

3. It can be interpreted from MICMAC analysis that majority of the factors/barriers chosen for this study fall under the linkage factors, thus it can be inferred that all the factors have strong dependence and strong driving power. Thus, all the barriers are heavily related to each other as well has a strong individual driving power and are volatile in nature. This calls for a careful implementation of IS from management by properly addressing these barriers.

4. Long legal procedure (B26) is most dominant barrier towards the successful implementation of IS and seeks utmost attention

5. Classification of the barriers based on their significance will help the decision maker to strategize decisions at various levels of an organisation.

6. The government should take steps to reduce the legal procedure required. This in turn will encourage industries to adopt IS. Furthermore, providing incentives such as tax cuts to the industries who adopt IS might lead to improved adoption of IS among their competitors or neighbouring industries.

7. NGO's and other non-profit organisations should increase their demands for effective waste management i.e., IS and actively conduct awareness campaign to masses so as to increase their knowledge about IS.

8. Industries can try to adopt the concept of Corporate Social Responsibility for better implementation of Industrial Symbiosis for the benefit of environment

9. Industries should try to shed their differences and coordinated effort between these industries must be made to consider recycling as significant option and their employees must be trained effectively. 
10. Enhancing the use of technology for activities such as, monitoring return flow of materials, gauging the optimal distance for improved and efficient transportation can make the implementation of IS easier and cost-effective.

The financial evaluation delineated that the IS system can make a generous commitment following 10 years to the two employments and potential incomes. Also, positive commitments are foreseen to local people abilities base, research and advancement and provincial personality. In the semi-quantitative scoring appraisal, the advancement scored vary for all markers. The far-reaching nature of this evaluation will be vital to represent the capability of modern advantageous interaction to districts, broadly furthermore, globally, with the end goal to propel neighbourhood endeavours with encouraging mechanical advantageous interaction and to see how these systems can be evaluated both quantitatively and subjectively.

\section{Conclusions and Further research}

The present extraction rate of raw materials is alarming and is not sustainable, this is because of constrained assets as well as because of the production of waste involved in the production processes, there is a need to for more awareness and reuse of waste and the concept of IS provided that model of reusing the waste as a raw material for some other industry. Thirty-three compelling factors go about as the powerful boundaries towards the usage of IS in an association. These factors have been distinguished from literature review and automotive expert's assessment. The specialist's inputs have been gathered and used to make SSIM matrix speaking to the interrelationships of those recognized factors. At that point these thirty-three elements were separated into eight levels based on their driving power from the final reachability matrix portraying their significance. The created ISM demonstrate has been utilized to empower re-manufacturing associations to take choices on vital components.

Though the ISM model helps in establishing the relationship and dependencies between the barriers, the barriers chosen might have a prejudice based on the person who decides it. This study identified 33 distinct barriers for the implementation of IS. In case, if the study requires modification suitable barriers can be included or employed barriers can be excluded befittingly. Fuzzy set theory (FST) can be used in accordance with MICMAC analysis to have better results. This model can be tested statistically using suitable tool. Case studies can also be used to hypothetically test the model. The study is expected to support with model to understand the relationship among barriers for effectively implementing IS in industries. However, the current study used ISM method to develop the model which has certain shortcomings like the strength of relationship is unclear. This can be improved utilizing the DEMATEL method in future.

\section{Conflict of interest}

The authors declare that they have no conflict of interest.

\section{References}

Akshay Mutha, Shaligram Pokharel (2009). 'Strategic network design for reverse logistics and remanufacturing using new and old product modules', Computers \& Industrial Engineering 56 (2009) 334-346.

Anthony S.F. Chiu, Geng Yong (2004). 'On the industrial ecology potential in Asian Developing Countries', Journal of Cleaner Production 12 (2004) 1037-1045.

Antonina Papathanasoglou, Maria Panagiotidou, Katerina Valta, Maria Loizidou (2016). 'Institutional Barriers and Opportunities for the Implementation of Industrial Symbiosis in Greece', Opportunities for the Implementation of Industrial Symbiosis in Greece Environmental Practice 18: 253-259 (2016).

Ariana Baina, Megha Shenoy, Weslynne Ashtona, Marian Chertowa (2010). 'Industrial symbiosis and waste recovery in an Indian industrial area', Resources, Conservation and Recycling 54 (2010) 1278- 1287.

B T Teh, C S Ho, Y Matsuoka, L W Chau, and K Gomi (2014). 'Determinant factors of industrial symbiosis: greening Pasir Gudang industrial park', 2014 IOP Conf. Ser.: Earth Environ. Sci. 18012162.

Bacudio, L. R., Benjamin, M. F. D., Eusebio, R. C. P., Holaysan, S. A. K., Promentilla, M. A. B., Yu, K. D. S., \& Aviso, K. B. (2016). 'Analyzing barriers to implementing industrial symbiosis networks using DEMATEL', Sustainable Production and Consumption, 7, 57-65 (2016).

Bux, H., Zhang, Z., \& Ahmad, N. (2020). 'Promoting sustainability through corporate social responsibility implementation in the manufacturing industry: An empirical analysis of barriers using the ISM-MICMAC approach', Corporate Social Responsibility and Environmental Management, 27(4), 1729-1748 (2020).

David Gibbs, Pauline Deutz (2005). 'Implementing industrial ecology? Planning for ecoindustrial parks in the USA', Geoforum 36 (2005) 452- 464. 
International Journal of Industrial Engineering and Operations Management (IJIEOM)

Volume. 3, No. 2, December 2021

Der-Horng Lee, Meng Dong, Wen Bian (2010). 'The design of sustainable logistics network under uncertainty', Int. J. Production Economics 128 (2010) 159-166.

Eric P. Jack, Thomas L. Powers and Lauren Skinner (2010). 'Reverse logistics capabilities: antecedents and cost savings', International Journal of Physical Distribution \& Logistics Management Vol. 40 No. 3, 2010.

Fadhel, Adel W., and Surendra M. Gupta (2020). 'Carbon Emissions and Energy Balance in the Design of a Sustainable Food Waste Network', International Journal of Industrial Engineering 2.1 (2020).

Frank Boons, Marian Chertow, Jooyoung Park, Wouter Spekkink, and Han Shi (2016). 'Industrial Symbiosis Dynamics and the Problem of Equivalence: Proposal for a Comparative Framework: Industrial Symbiosis Dynamics', WILEY (2016).

Frank Boons, Wouter Spekkink, Yannis Mouzakitis (2011). 'The dynamics of industrial symbiosis: a proposal for a conceptual framework based upon a comprehensive literature review', Journal of Cleaner Production 19 (2011) $905 \mathrm{e} 911$.

Hung-Suck Park, Eldon R. Rene, Soo-Mi Choi, Anthony S.F. Chiu (2008). 'Strategies for sustainable development of industrial park in Ulsan, South Korea', Journal of Environmental Management 87 (2008) 1- 13.

Jacqueline Li, Shu-Yuan Pan, Hyunook Kim, Jean H. Linn, Pen-Chi Chiang (2015). 'Building green supply chains in eco-industrial parks towards a green economy: Barriers and strategies', Journal of Environmental Management 162 (2015) $158 \mathrm{e} 170$.

Joseph Sarkis, Marilyn Michelle Helms and Aref A. Hervani (2010). 'Reverse Logistics and Social Sustainability', Corp. Soc. Responsib. Environ. Mgmt. 17, 337- 354 (2010) Published online 14 January 2010 in Wiley Online Library.

Judith L. Walls and Raymond L. Paquin (2015). 'Organizational Perspectives of Industrial Symbiosis: A Review and Synthesis', Organisation \& Environment 2015, Vol. 28(1) 32-53 2015 SAGE Publications.

Kannan Govindan, Hamed Soleimani, Devika Kannan (2015). 'Reverse logistics and closed-loop supply chain: A comprehensive review to explore the future', European Journal of Operational Research 240 (2015) 603-626.

Kawanaka, Takaaki, Hiroshi Yamashita, and Shoichi Kaneko (2019). 'Deviation Degree between Ideal and Real Domain Transition Probabilities in Resource Circulation Considering the Production Synchronization Ratio', International Journal of Industrial Engineering 1.2 (2019): 154-167

Kumar, K., Dhillon, V. S., Singh, P. L., \& Sindhwani, R. (2019). 'Modeling and analysis for barriers in healthcare services by ISM and MICMAC analysis', In Advances in Interdisciplinary Engineering (pp. 501-510). Springer, Singapore (2019).

Li Sun, Wouter Spekkink, Eefje Cuppen and Gijsbert Korevaar (2017). 'Coordination of Industrial Symbiosis through Anchoring', MDPI (2017).

Lu, C., Wang, S., Wang, K., Gao, Y., \& Zhang, R. (2020). 'Uncovering the benefits of integrating industrial symbiosis and urban symbiosis targeting a resource-dependent city: A case study of Yongcheng, China', Journal of Cleaner Production, 255, 120210, (2020).

Mallawaarachchi, H., Sandanayake, Y., Karunasena, G., \& Liu, C. (2020). 'Unveiling the conceptual development of industrial symbiosis: Bibliometric analysis', Journal of Cleaner Production, 258, 120618 (2020).

Md Abdul Moktadir, Syed Mithun Ali, R. Rajesh, Sanjoy Kumar Paul (2018). 'Modeling the interrelationships among barriers to sustainable supply chain management in leather industry', Journal of Cleaner Production 181 (2018) $631 \mathrm{e} 651$.

Neves, A., Godina, R., G Azevedo, S., Pimentel, C., \& CO Matias, J. (2019). 'The potential of industrial symbiosis: Case analysis and main drivers and barriers to its implementation. Sustainability', 11(24), 7095 (2019).

Pajunen, N., Watkins, G., Husgafvel, R., Heiskanen, K., \& Dahl, O. (2013). 'The challenge to overcome institutional barriers in the development of industrial residue based novel symbiosis products-Experiences from Finnish process industry', Minerals Engineering, 46, 144-156 (2013).

Pajunen, N., Watkins, G., Wierink, M., \& Heiskanen, K. (2012). 'Drivers and barriers of effective industrial material use', Minerals Engineering, 29, 39-46 (2012).

Patala, S., Salmi, A., \& Bocken, N. (2020). 'Intermediation dilemmas in facilitated industrial symbiosis', Journal of Cleaner Production, 261, 121093 (2020).

Ram Nidumolu, C.K Prahalad, M.R Rangaswami (2013). 'Why sustainability is now the key driver of innovation', IEEE Engineering Management Review (Volume: 41, Issue: 2, second Quarter 2013).

Raut, R., Narkhede, B. E., Gardas, B. B., \& Luong, H. T. (2018). 'An ISM approach for the barrier analysis in implementing sustainable practices', Benchmarking: An International Journal (2018).

Tao, Y., Evans, S., Wen, Z., \& Ma, M. (2019). 'The influence of policy on industrial symbiosis from the Firm's perspective: A framework', Journal of Cleaner Production, 213, 1172-1187 (2019).

Tseng, Ming-Lang and Bui TatDat (2016). 'Identifying eco-innovation in industrial symbiosis under linguistic preferences: A novel hierarchical approach', Journal of Cleaner Production (2016). 
Turan Paksoy, Nimet Yapici Pehlivan \& Eren Özceylan (2012). 'Fuzzy Multi-Objective Optimization of a Green Supply Chain Network with Risk Management that Includes Environmental Hazards', Human and Ecological Risk Assessment: An International Journal (2012).

URŠKA FRIC (2015). 'Socio-cultural aspects and barriers of industrial symbiosis - the good, the bad and the ugly: which ones matter and why?', WSEAS (2015).

Vasileios Rizos, Arno Behrens, Terri Kafyeke, Martin Hirschnitz-Garbers and Anastasia Ioannou (2015). 'The Circular Economy: Barriers and Opportunities for SMEs', CEPS Working Document No. 412 / September 2015.

Vasileios Rizos, Arno Behrens, Wytze van der Gaast, Erwin Hofman, Anastasia Ioannou, Terri Kafyeke, Alexandros Flamos, Roberto Rinaldi, Sotiris Papadelis, Martin Hirschnitz-Garbers and Corrado Topi (2016). 'Implementation of Circular Economy Business Models by Small and Medium-Sized Enterprises (SMEs): Barriers and Enablers', Implementation of Circular Economy Business Models by Small and Medium-Sized Enterprises (SMEs): Barriers and Enablers.

Vinodh, S., \& Asokan, P. (2018). 'ISM and Fuzzy MICMAC application for analysis of Lean Six Sigma barriers with environmental considerations', International journal of lean six Sigma (2018).

Weslynne S. Ashton (2011). 'Managing Performance Expectations of Industrial Symbiosis', Business Strategy and the Environmen 20, 297-309 (2011).

Yan Zhang, Hongmei Zheng, Bin Chen, Meirong Su, Gengyuan Liu (2014). 'A review of industrial symbiosis research: theory and methodology', Higher Education Press and Springer-Verlag Berlin Heidelberg 2014.

Bacudio, L. R., Benjamin, M. F. D., Eusebio, R. C. P., Holaysan, S. A. K., Promentilla, M. A. B., Yu, K. D. S., \& Aviso, K. B. (2016). Analyzing barriers to implementing industrial symbiosis networks using DEMATEL. Sustainable Production and Consumption, 7, 57-65.

Kosmol, L., \& Otto, L. (2020, January). Implementation barriers of industrial symbiosis: a systematic review. In Proceedings of the 53rd Hawaii International Conference on System Sciences.

\section{Biographies}

Vimal K.E.K

Asela K. Kulatunga

Lakshmanakumar Veeraragavan

Mahadharsan Ravichandran

Jayakrishna Kandasamy

(C) IEOM Society International 
International Journal of Industrial Engineering and Operations Management (IJIEOM)

Volume. 3, No. 2, December 2021 